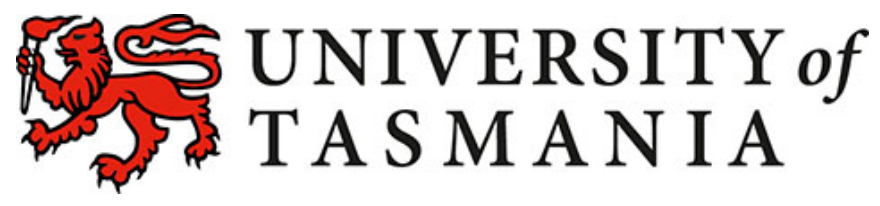

\title{
The Challenge of Existential Social Work Practice
}

\author{
by \\ Mark Griffiths \\ B.A., B.S.W. University of Melbourne \\ M.S.W. RMIT University \\ School of Social Sciences
}

Submitted in fulfilment of the requirements for the Doctor of Philosophy in Social Work University of Tasmania October 2017 


\section{Statements and Declarations}

\section{Statement of Originality}

This thesis contains no material which has been accepted for a degree or diploma by the University or any other institution, except by way of background information and duly acknowledged in the thesis, and to the best of my knowledge and belief no material previously published or written by another person except where due acknowledgement is made in the text of the thesis, nor does the thesis contain any material that infringes copyright.

Signed

Mark Griffiths

\section{Authority of Access}

The publication titled The Challenge of Existential Social Work Practice, which forms a part of this thesis, is a publication, and is subject to commercial contract with Palgrave MacMillan, London. No access or loan of any part of this document is permitted without the direct permission of Palgrave Macmillan, the copyright holders. The remaining unpublished content of the thesis may be made available for loan and limited copying and communication in accordance with the Copyright Act 1968.

Signed

Mark Griffiths 


\section{Statement of Ethical Conduct}

The research associated with this thesis abides by the international and Australian codes on human and animal experimentation, the guidelines by the Australian Government's Office of the Gene Technology Regulator and the rulings of the Safety, Ethics and Institutional Biosafety Committees of the University.

Signed

Mark Griffiths 


\section{Exegesis on 'The Challenge of Existential Social Work Practice'}

\section{Contents}

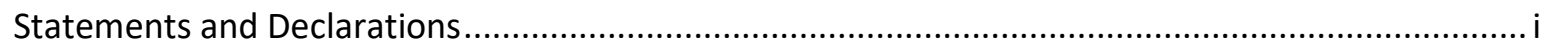

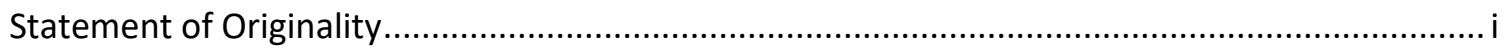

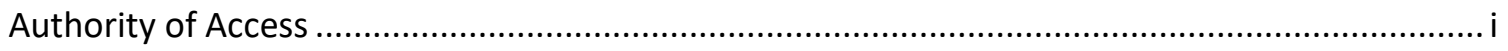

Statement of Ethical Conduct ................................................................................................. ii

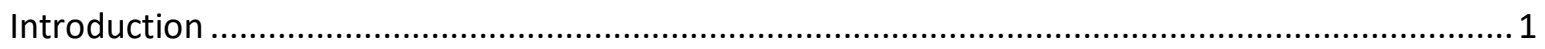

My involvement in existential thought: Why existentialism? ....................................................... 5

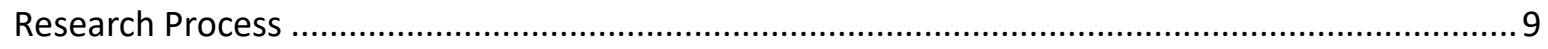

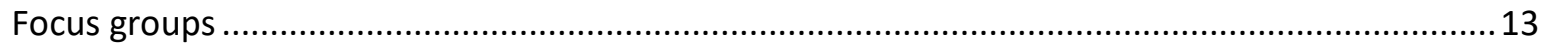

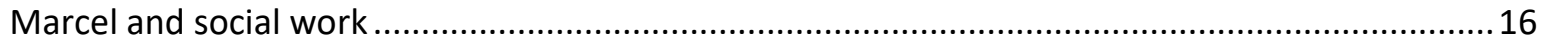

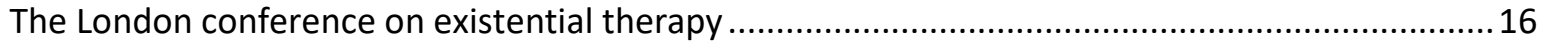

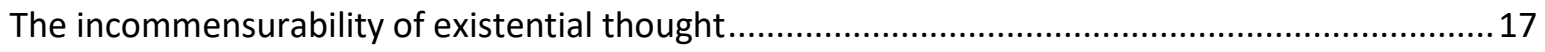

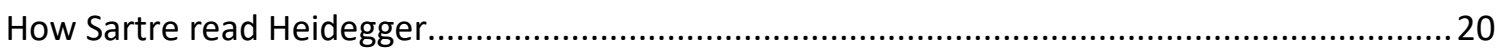

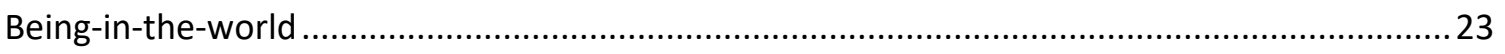

Incommensurability and lessons from the secondary literature ................................................25

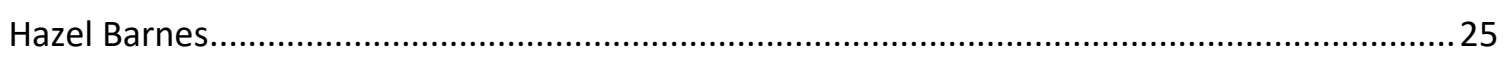

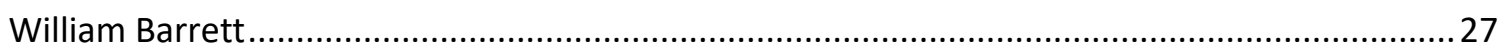

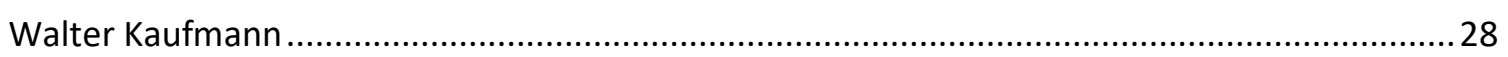

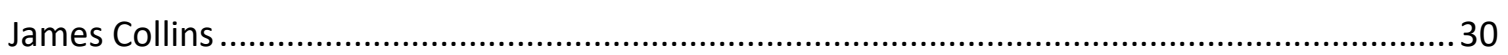

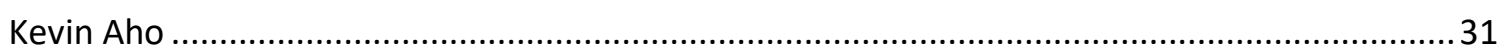

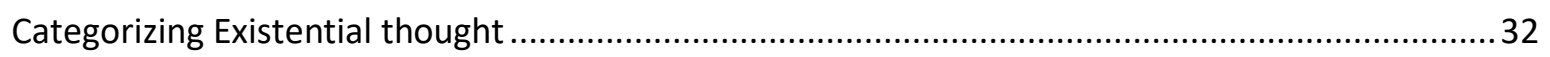

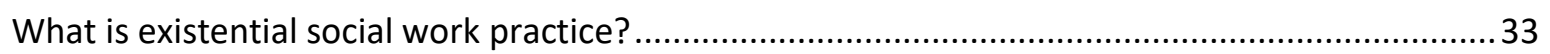

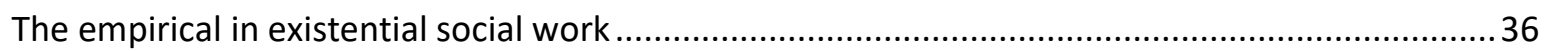

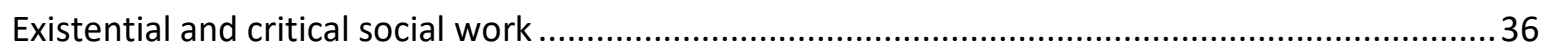

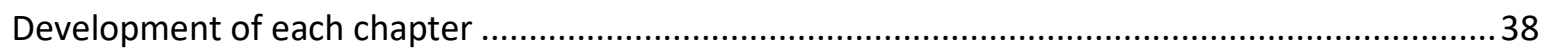

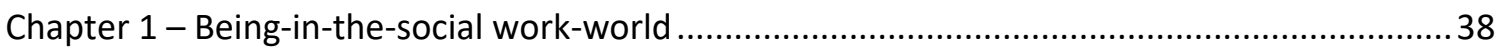

Chapter 2 - Immortal social work: The first existential social work practice ................................38

Chapter 3 - Existential social work comes of age …............................................................... 39 


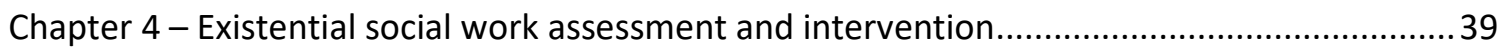

Chapter 5 - Existential social work in social policy, social movements and team work ...............40

Chapter 6 - Creative social work and existential social work.....................................................4

Chapter 7 - Evidence-based practice and existential social work ................................................42

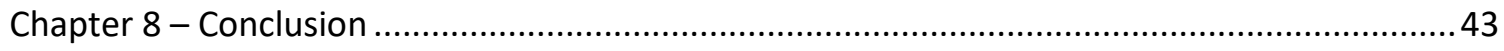

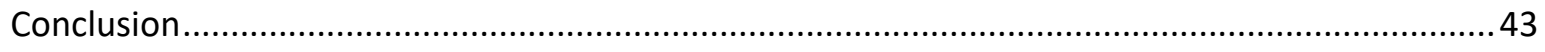

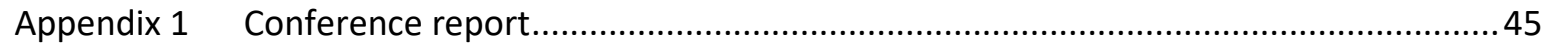

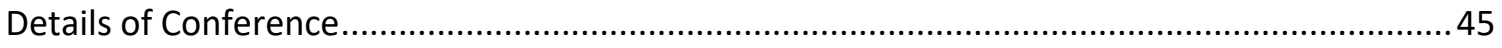

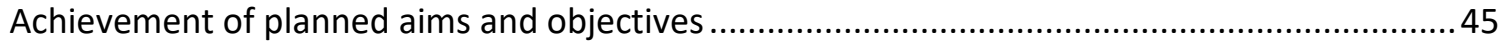

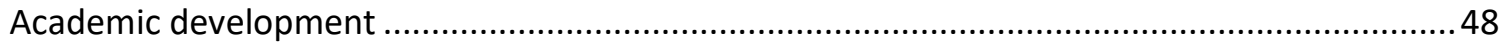

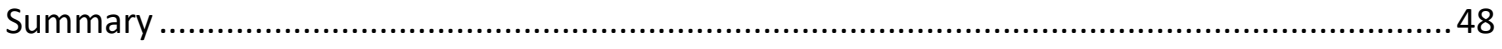

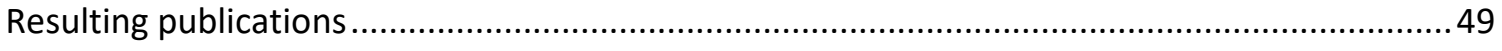

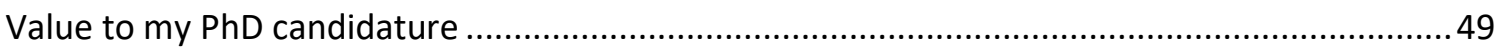

Recommendation for future attendance and other relevant information .................................50

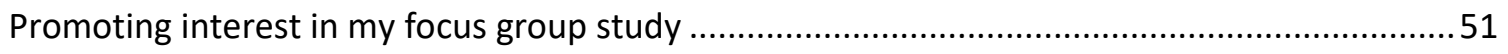

Appendix 2 Focus group advertisement for AASW publications ...............................................52

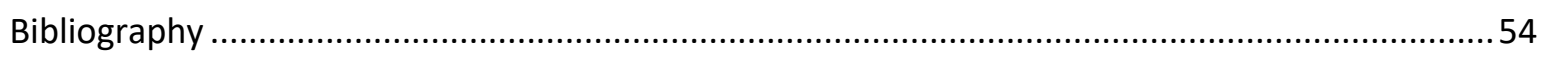




\section{Introduction}

The purpose of this exegesis is to describe the theoretical, biographical, and practical journey of producing the text of the book, The Challenge of Existential Social Work Practice. The exegesis is Part A of the complete thesis, and Part B is the book itself, which is not submitted as a separate document, as it is subject to commercial contract with the publishers, Palgrave Macmillan. Part C is an article titled 'Applying Gabriel Marcel's Thought in Social Work Practice', which was published in Marcel Studies in 2015 and is freely available on line. The three documents comprise my attempt to make sense of an existential approach to social work practice in the $21^{\text {st }}$ century.

In this exegesis, I critically examine the writings of key existential thinkers such as Jean Paul Sartre, Gabriel Marcel, and Martin Heidegger as they apply to social work. The view that existential thought is incommensurable with the diversity of existential perspectives is rejected. There are some fundamental concepts shared among existential thinkers. Two examples are the ideas of being-in-the-world and lived experience, which, I argue, are common to all the thinkers mentioned above.

My focus is the application of existential thinking to social work practice. The corpus of existential creative writing, which includes literature, plays, films, and diaries, features less in my work than does explicitly philosophical writing. My view is that the philosophical works are most relevant to social work practice. However, existential creative writing does highlight important features of existential thought in a way that enhances our understanding of the underlying philosophy. Albert Camus, for example, wrote more creative works than philosophical ones, and as such this exploration of existential thought must cover a broad cross-section of existential writing limited by my focus on social work. For example, I refer to 'The Guest' (1958), a short story by Camus. I have used this short story because I believe that it brings out the dilemma of the helping person in a hostile environment in their role as both a social control and potential agent of social change. For me, Camus's story exemplifies the challenge of being in both roles, taking both responsibilities seriously and facing the challenges of this dilemma.

'The Guest' is about a French school teacher who also provides a basic welfare service to the local Arab community during the Algerian revolution. Social work frequently operates within conflict situations where competing sides are causing harm, and it attempts to provide a humane solution. Like the school teacher in this fictional story, the concrete situation of the social worker requires that the he or she balance their social control functions with their 
attempts to find a humane solution that is faithful to his or her social justice objectives. My perspective on this existential social work practice can only be personal, and does not claim to be objective. Nor can it be my final word; I am on a journey of discovery that continues to challenge and change my perspective, even as I write these words. As a social work practitioner, I must create my personal response in the moment of practice.

Later, I examine some of the key influential secondary sources on existential thought, writings by Hazel Barnes (1959), Walter Kaufmann (1972), James D. Collins (1954), William Barrett (1961) and Kevin Aho (2014). These writers, among others, provide useful introductory texts on the topic of existentialism. They have all written extensively on the topic, and have helped promote and shape people's understanding of it. I have chosen these writers because they express a very diverse range of views. Their writings cover the last sixty-five years, beginning with James Collins’ The Existentialists, published in 1952, and finishing with Kevin Aho’s introductory text Existentialism (2014).

There is also a significant body of work on existential therapy, but its application to social work practice in general has rarely been explored (Shapiro, 2016). While I do not practice existential therapy, I have studied its main approaches and how they can apply to social work practice. My book aims to address the distinction between existential therapy as a clinical practice and existential social work practice; the latter of which, in direct practice, aims for a broader range of interventions than does therapy. I also apply an existential social work practice framework to social policy, leadership and team work, to social movements, program reviews, evidence-based practice and social group work. Social work encompasses a range of methods and roles, and an existential social work approach needs to address all these aspects.

There is also a considerable literature on existential social work practice. There are writers who identify with the existential label, such as Neil Thompson (1992), Donald Krill (1978), and Jim Lantz and Joseph Walsh (2007). Other works that I examine have not been labelled "existential”. However, I am certainly not the first writer to have applied this label to the Otto Rank-inspired, Functional School of social work practice. There is also a range of lesser known social work writers - such as Ruth Wilkes (1981) - who have been influenced by existential and phenomenological thought. Much of this material exists in early social work journal articles, some of which are not available on current electronic databases (Taft 1928).

While I cannot claim to have made a complete analysis of all existential social work writing in my book, I have covered the key texts and articles on the subject. Many of these 
existential social work authors have also written articles on other topics. Where relevant, I have also reviewed these writings, including Neil Thompson's (2006) anti-discriminatory practice theory, which is informed by Sartre's critical social existential theories, and Jim Lantz's (2000) cognitive, family and short-term therapy work, which is informed by Viktor Frankl’s (2004) logotherapy. I also examine other existential writers, such as Gabriel Marcel (1966).

Finally, although I focus on theory in this exegesis, I have not excluded practice issues or examples from the discussion where these might help clarify a point. This exegesis contains a chapter-by-chapter elaboration and interpretation of the texts that inform my book.

I will also address aspects of my biography as a social worker in the exegesis to illuminate my practice, theoretical preferences and viewpoint. The writing of the exegesis has informed my book. My current work in the family violence field and in facilitating men's behaviour change programs shapes some of my preferences. For example, my need to critically engage with the work of Alan Jenkins (2009), which is aligned with narrative therapy, reflects my current employment in family violence work. It also requires me to examine theoretical perspectives, such as narrative therapy, that I regard as compatible with existential theory (Richert, 2010).

I also bring my personal and political values, preferences and biases to my professional life. My preference for an existential approach to social work is shaped by it being a "way of life” philosophy, a practical moral perspective on how to live a fulfilling life. I combine this with other viewpoints which I find useful; for example, cognitive developmental and functional theory, and some postmodern social construction theories, such as narrative therapy. In this respect, I have done what other existential writers have been doing since the first explicit uses of existential thought: combining it with other compatible theoretical viewpoints.

In this context, it is important to emphasize that I am not arguing for the superiority of the existential perspective over other views, nor claiming that it has some monopoly on wisdom. Rather, I argue that the existential view has been marginalized within social work by more dominant theories, such as eco-systems thinking, critical theory and psychodynamic perspectives. One of the challenges is discovering how existential thought can bring insight into and enhance other complementary theoretical views. I have already mentioned the work of Alan Jenkins (2001; 2009), in which he has written from a narrative, feminist perspective, and also using restorative justice practices, about how to work effectively with violent or abusive (including sexually abusive) men. Jenkins' work has been influential over the past 
two decades among facilitators of men's behaviour change programs in Australia. Jenkins draws our attention to a risk that workers may select passages of his practice suggestions and apply them without a deep understanding of his overall framework, and this may lead to the inappropriate use of his questions and phrases. Eclectic borrowing of ideas from a range of approaches runs the risk of being what might be described as shallow direct practice. Good practice emerges when practitioners integrate theory and practice, and apply it appropriately. Consequently, part of my journey in writing this work has been my engagement with Jenkins' thought, as well as with that of other writers who have already integrated existential and narrative approaches, such as Richert (2010).

Existential theory can engage with a range of other theoretical appeoaches, such as solution therapy, cognitive theory, psychoanalytic theory and systems theory, and it remains very popular. Aho (2014) documents existentialism's relevance to today's issues through its contribution to critical and race theories and various other theories of oppression, as well as its critique of all-pervasive technology and its impact on the environment. He also considers its links to Buddhist thought in dealing with chronic suffering, and its application in health and therapy through the popular phenomenological research approach to peoples' experiences, and through the world-wide existential therapy movement.

These are just some of the theory's current applications. I can see a danger that existential thought could be regarded as some kind of panacea for every problem facing social work. I am not claiming this. Rather, I am noting that existential thought continues to be vibrant after a significant amount of time. Perhaps this is partly due to its emphasis on concrete, worldly issues, and on the concept of lived experience, which has become very popular in the social sciences.

Social work has a long history of engagement with existential ideas. My book aims to explore some of this history, which has not been well documented in any one publication to date. This exegesis documents the ways in which my perspective on existential social work practice builds upon previous efforts by writers, such as Krill (1978) and Thompson (1992), as well as where it differs. Part of this process of engaging with previous existentiallyinformed social work writers involves addressing my own background in existential thought. 


\section{My involvement in existential thought: Why existentialism?}

I first came across existentialist thought when taking a course on continental European philosophy taught by Dr Max Charlesworth at Melbourne University. The set text was Existentialism from Dostoevsky to Sartre, by Walter Kaufmann (1972). I took the course in 1975, five years before Sartre's death. We first examined Sartre's famous public lecture of 1946, Existentialism is a Humanism, (Sartre, 2007) in tutorials, and I was aware at the time that Sartre had embraced Marxism and was aligned to the Maoists in France. I remember the crucial question in this essay was Sartre's embrace of the Kantian categorical imperative that 'in committing myself, one also commits the whole of humanity' (Sartre, cited in Kaufmann, 1972, p. 305). For this view, he was criticized, both by his contemporaries, and in our tutorials, because it appeared to be a regression to a derivative ethical position from Kant and not a genuinely new philosophy. This move by Sartre perplexed me at the time. In retrospect, Sartre was making an impromptu public speech at the height of his fame and popularity. He was aware of a serious flaw in existentialism's popular advocacy of freedom as the highest value. How do you deal with the rationalist egoist who chooses to use his freedom for selfinterest, self-aggrandizement, or other selfish purposes? Sartre had returned to Kant to address this flaw. Sartre's position cannot be dismissed as a mere off-the-cuff comment; Sartre published this speech, even though he later expressed regret at doing so. His regret probably derives from the ease with which his adversaries on the left were able to dismiss his "new” philosophy as Kantian and idealist.

As a young student, I remember being fascinated (and a little overwhelmed) by the complexity of philosophy and by the obviously greater expertise of some of my fellow students. One student introduced me to the Marxist-Leninist canon as interpreted through Maoist ideology. It seemed to offer a ready-made way through the mystification of so much philosophy. Doing a philosophy major also means studying philosophers, like George Berkeley and his analytical philosophy, and Marxism provided a radical tool to understand and critique this thought. It was like finding a new belief system or religion that explains everything. It wasn't a big step to embrace Sartre, given his seeming adherence to similar positions. Besides having a sharp political mind, Sartre always seemed to be on the side of the underdog in world affairs and that was a philosophy that suited me. I now view Maoism as a form of negative rebellion, as Bill Moyer describes it in his book Doing Democracy (2001). Moyer's book was very influencial on me in trying to make sense of social 
movements in social work and of the need to adhere to democratic, non-violent approaches in achieving sustainable social change.

I remained interested in Marxist thought through Sartre's work, although I found that his obscure, verbose writing made it difficult to understand. Sartre’s literary estate, through his publishers, continued to release works in English translation after Sartre's death, so it seemed to me as though Sartre was still alive, even throughout the 1990s. I gradually lost interest in Marxism, and with its demise in my life Sartre appeared passé. But I still found something in his writing that kept me interested, an interest that was reignited many years later when I discovered that Neil Thompson (1992) had applied Sartre's thought to social work practice.

Social work itself brought me into contact with other academics influenced by existential thought, such as Dr Peter O’Connor, a social worker and writer with a private psychotherapy practice, who had been influenced by the writings of Carl Jung and Søren Kierkegaard. Anything existential had always attracted my attention, but the obscurity of Kierkegaard's philosophy, with its obsession with Christianity, was of little interest to me. Partly, I was still rejecting overtly Christian thinkers at this stage, due to my very negative experiences with Christianity growing up. I now view my early rejection of Kierkegaard as shallow.

What was interesting about O’Connor was seeing an obviously deep thinking therapist use philosophy in a therapeutic way. O’Connor had read these thinkers thoroughly and had absorbed their ideas. In his lectures, O’Connor combined Kierkegaard's overarching philosophy with very pragmatic techniques taken from a range of other sources to create his unique approach to therapy. At this stage, I was not attracted to any sort of private practice social work as was advocated by the emphasis on counselling in my social work course.

My social work career led me into the public welfare areas of child protection, youth justice, and community health, and eventually into management of small non-government agencies delivering services to statutory clients, usually on a voluntary basis. There was a palpable tension between the roles of social control agent and advocate for social justice for highly marginalized young people. I had previously experienced student placements in hospitals and mental health settings, where I had enjoyed the work but had disliked the dominance of the medical model.

Public welfare seemed to provide social workers with more freedom to make a difference in people's lives. This is an area where social control looms large, where harmful behaviours and evil and good actions are everyday concerns, and where engagement is the 
real challenge. Existentialism appeared to take a back seat to other theories, like functional theory, in working out how to improve a marginalized family's coping skills through, for example, writing a family functioning profile and identifying services that could be improved. A family with child protection issues that received financial counselling assistance could improve in other areas through this systematic process of assessment and intervention.

Over time, I became more interested in working with hard to reach adolescents, and developmental theory provided the tools to determine maturity levels and to respond appropriately to the corresponding level of understanding and characteristic ways of dealing with the world. For example, a peer-orientated young person who ignored adult communication needed a completely different engagement strategy from a young person who had developed some individual ethical standards. Somehow, I stumbled across a draft chapter of James Barber's Beyond Casework, which would eventually be published in 1991. In this book, Barber presented a conflict management approach to working with involuntary clients which placed the emphasis on creating an expanded negotiable territory with the client. This was accomplished by being succinct about the non-negotiable aspects of your involvement with the client (Barber, 1991, pp. 42-60). Other writers (Trotter, 2015; Ivanoff, Blythe and Tripodi, 1994) have subsequently addressed the matter of involuntary or statutory work, but at the time, it was Barber's work that had a powerful impact on my daily practice.

I began as project co-ordinator of the first restorative justice group conferencing pilot project in Victoria in 1995, and I remained involved in this work for over ten years. In retrospect, this experience taught me the importance of social work in a social movement in creating new services for and approaches to old problems, like youth crime. At the time, I had not connected my professional work to existential thought, as restorative justice seemed more connected to family theory, empowerment theory, and group work processes. I was studying family therapy at the Bouverie Clinic to fill a gap in my knowledge of how to intervene successfully with families. But the existential themes are there in restorative justice processes in the ideas of taking responsibility, allowing the client to creatively decide (with the help of their support group) on their own plan to make amends, and in using story-telling and making personal statements about the lived experience of the impact of an offence.

There was always a spiritual element in how I facilitated group conferences to assist in conflict resolution. I worked hard to bring a spiritual energy to the room, through extensive preparation of all participants and the creation of a peaceful environment. Firstly, effort went into making the sessions safe forums. Much of the work you do in a pilot project in on "firsts". There is an anonymized illustration of this process in the third chapter of the book. I 
remember channelling spiritual energy into that room long before the participants, still traumatized by events, attended the conference. On another occasion, I was required to facilitate a group conference in front of a government minister and his entourage. You need to truly believe in a program to confidently perform under such circumstances. It took ten years from the first conference in 1995 for a legislated, state-wide program to be implemented. This process is described in the book's fifth chapter. I also started practicing yoga, and reconnected with the contemplative elements of Christianity - it was the work of Buddhist writers like Thích Nhất Hạnh (1997) that encouraged me to explore the positive roots of Christianity. I also completed a Masters of Social Work on 'Teaching Yoga in Addiction Recovery’ (2007), also under the supervision of Professor Bob Pease.

I became aware of existential social work thought when I began this $\mathrm{PhD}$, while teaching social housing workers and social workers at a higher education level. This was primarily through Neil Thompson's (1992) existential anti-discriminatory practice approach, which was informed by his study of Sartre's attempt to reinvigorate Marxism through existential thought. From a teaching perspective, students seemed to grasp Thompson's (2006) person, cultural and structural (PCS) model (see Figure 1, below), and they quickly applied it in their own work.

I would ask the students to imagine every person they work with as having Thompson's three elements or dimensions to their existence. Thompson linked his model directly to Sartre's existential philosophy, in which the social worker can challenge and externalize discourses that are oppressive and help the person to find new approaches that give them a sense of freedom and responsibility. I was hoping that the students would understand that the client in front of them (and the other people around them) had these structural and cultural oppressions, in addition to the personal oppressions that were more readily apparent. 


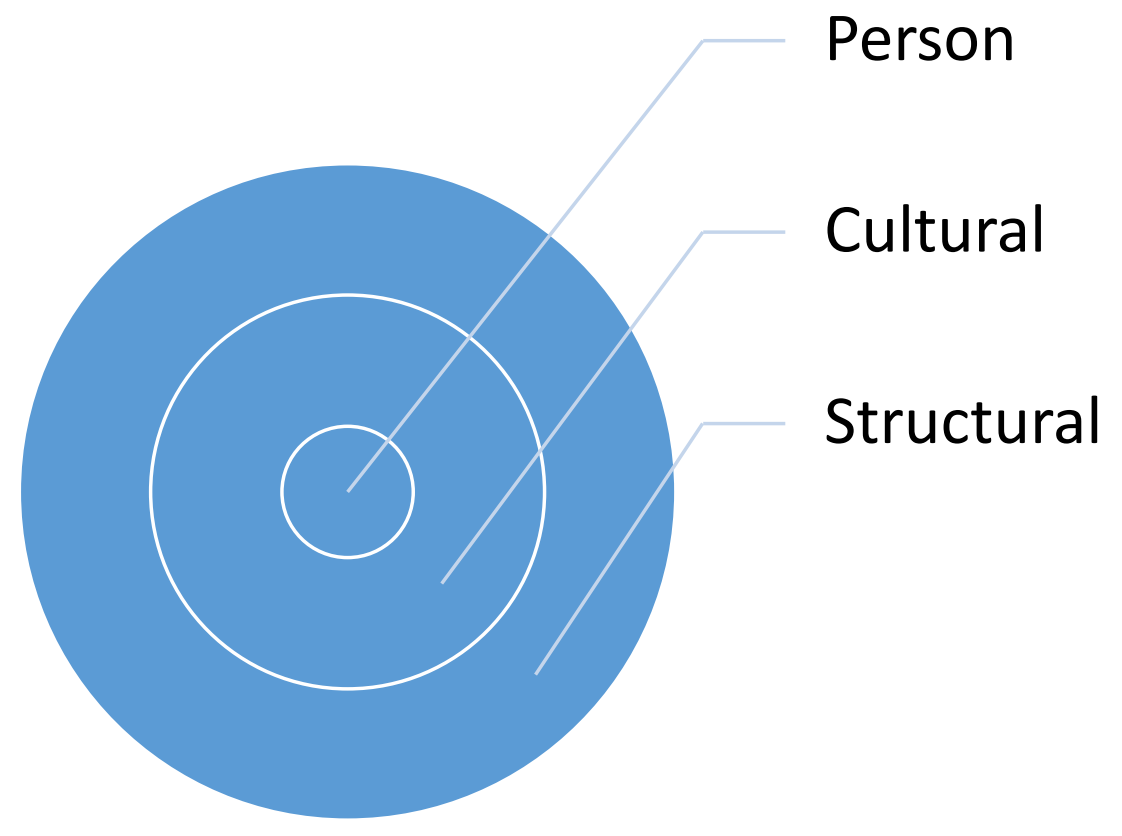

\section{Research Process}

The research process for this $\mathrm{PhD}$ may be organised and discussed under a number of different qualitative methodologies; These are,

- biographical data, as described in the previous section on my historical engagement with existential thought and as described in my history as a social worker in some of the examples used in the text, The Challenge of Existential Social Work Practice. Biographical material as a research approach is also documented in how I immersed myself into existential thought opportunities that were available to me over the last four years of this research, which are described immediately after this paragraph.

- Secondary data analysis, including analysis and comment on existing existential writing in social work, re-examination of practice examples and case studies from the published literature, such as the discussions of RD Laing's work in Chapter 4 of the book,

- Reflective practice, particularly making use of Marcel's concept of primary and secondary reflection, with the latter referring to a deeper level of reflection that involves the person taking responsibility for their involvement in whatever is being reflected on and it's meaning for them (Marcel, 1987). My reflective practice is also 
informed by social work approaches to critical reflection and practitioner research (Fook, Gardner, 2013, Fuller, Petch 1995).

- Focus Groups, as described in the next section of this Exegesis.

During the PhD, I immersed myself in existential thought. I have become familiar with the existential therapy movement in Australia by attending a number of professional workshops organized by the Australia-based Centre for Existential Practice. The centre is primarily aligned with the phenomenologically informed work of Ernesto Spinelli (2007) and the philosophically informed existential therapy of Emmy van Deurzen (2010). I have also attended two conferences, one in Melbourne and one in Sydney, facilitated by Professor Mick Cooper, a leading academic writer on existential therapy in all its current forms.

In August 2013, I attended the Kierkegaard in the World Conference at the Australian Catholic University. There were leading global scholars of Kierkegaard attending this conference, including C. Stephen Evans, John Lippitt, Charles Guignon, and Daphne Hampson. I learned from this conference that there are many different interpretations of Kierkegaard's thought. Various speakers approached his work from established perspectives, including the orthodox Christian, existential, feminism-informed, postmodern, and critical.

I became involved in three weekly reading groups, struggling through complex existential phenomenological texts such as Heidegger's Being and Time (1962), MerleauPonty's The Phenomenology of Perception (1962), and Hegel's Science of Logic (2009). In each of these reading groups, members (all $\mathrm{PhD}$ students of various disciplines) would read an agreed upon chapter or so, and then hold a discussion on the issues raised. I found this process helpful in getting through these texts.

In addition, I have attended numerous philosophy courses on Hegel, Camus, Sartre and Heidegger organized by the Melbourne School of Continental Philosophy, including courses by leading academics, such as Mark Wrathall, on 'The Late Heidegger', and two courses on Sartre's existential biographies and his Critique of Dialectical Reasoning, Volume 1, as well as a course on Sartre and Lacan, and another on Camus.

As part of the reading group on Hegel's Science of Logic, I helped organize the 2014 summer school on Hegel and social movements at the Wheeler Centre in Melbourne. I mention this as an example of the phenomenon that it is often the inadvertent discoveries in the course of your work that seem to reap the rewards. Organizing this summer school involved contacting and becoming familiar with leading overseas academics specialising in 
Hegel and his philosophy. My email contact with Robert Wallace (2005) began here, and reading his work on Hegel has shaped my thinking.

It was during this period that I discovered what Wallace describes as Hegel's greatest discovery, his concept of true infinity, as distinct from spurious infinity. True infinity encompasses the finite; spurious infinity proposes an infinite being that is separate from the finite world - this is comparable to the traditional view of God as an infinite being, completely separate from the finite world of matter. Hegel developed his concept of true infinity from his reading of the Gospels and of the revelation contained within the incarnation of Christ. For Hegel, the truly infinite must encompass the finite by definition. I was discovering this world of Hegel while surrounded by critical thinkers who had been inspired by Marx’s reading of Hegel, which explicitly rejects these theological views. Wallace is not a theologian but rather a philosopher open to spirit, and he approaches Hegel from this perspective.

The Hegel reading group was organized by a very friendly and inviting Marxist named Andy Blunden. The Hegelian philosophical world seems to be divided into two camps, the Marxist and the theological, and these operate completely independently of each other. I discovered that Blunden was known among members of the theological camp and was respected by writers like Robert Wallace. He had a deep understanding of Hegel's work and its role in social movements. He made the point that Hegel's view on the state was akin to our modern conception of a social movement. For Hegel, the state was really about people coming together to sort out social issues collectively. Society itself was something like a social movement, inspired by ideas that drove their new consciousness of the need for change. I understand when Hegel speaks about ideas shaping our world and changing things. Social movements are created by people and fought for by people. The ideas or concepts that shape these movements and our world need social workers to work alongside others to progress them.

Sartre, Hegel, and other critical theorists like Habermas (1981), in his theory of communicative action, have made a significant contribution to social existential thought in their study of the role of group processes and social movements in social change. My exchanges with Robert Wallace and Andy Blunden broadened my understanding of social movements to include self-help groups like the Twelve-step programs, which aim to change people's consciousness in order to address addictive behaviours. I had previously attended numerous Alcoholics Anonymous and Narcotics Anonymous meetings as an observer, because they were inspiring and because they had many parallels with restorative justice 
conferences in their narrative style of problem solving. Working in family violence also made me very conscious of how social movements shape and have shaped service delivery.

In recent times, it has been the emergence of an existentially inspired view of Jesus' original teachings that has most piqued my interest. The "existential Jesus" has been divested of the Christian churches' dogmas. This is the Jesus that rejected dogmas, traditions and beliefs in favour of living fully within being or current reality. In doing a course on his early Christian writings, I discovered that Hegel (1948), as early as 1796, had already understood much of what had only recently been written about the so-called existential Jesus. He also understood that Christ needed the church, first as a social movement and later as an institution, in order for his teachings to spread.

Today, Christ's thought cannot be separated from the institutional history that followed his life. This was a revelation to me, and sent me back to discovering the roots of modern existentialism in Hegel through modern philosophers - such as Robert Solomon (1987) who were openly existential thinkers, and embraced Hegel as an existential thinker, too. I began discovering existentialists in unusual places. For example, Gerald Corey (2013) took up an existential viewpoint as a meta-theory while writing numerous standard textbooks on counselling in America, which reviewed all the therapeutic approaches. As was and is the case for many theorists and practitioners, existentialism and existential therapy provided his meta-theory.

Perhaps the book that has most influenced my approach is one I stumbled upon, Human Existence and Theodicy (1992), by Robert Sutton, which compares Christ's parables with the work of Camus. In this book, Sutton draws together these two thinkers to address the problem of evil, or human suffering created by natural or human causes; similarly, much of social work is deals with addressing the consequences of human suffering and the behaviour that causes it. What Sutton finds is that both men adopted a very pragmatic approach and had a willingness to accept that, given life's vicissitudes, the only response that makes sense is one of compassion for others and of living life to the fullest through love for and mercy to yourself and others. I found it curious that Sutton should quote his teacher Kessler as stating that finite beings can affirm that 'life is not ultimately precarious' (Sutton, 1992, p. xii). What does this mean? Was this some reversion to a notion of an afterlife?

I began a very fruitful conversation by email with the author who was pleased that his book had caught my interest. Through that conversation, I came to think what Kessler's comment means is that we can potentially live our lives not driven by anxiety and fear if we have hope that we live in a world that is supporting our efforts to do good and make a 
difference. Despite all the horrors, these thinkers believed that our world did have this capacity, and that living ethically involves putting yourself in synch with its abundance. I find, at this deeper level, that the diversity of existential thought coalesces around this notion: Heidegger’s being, True Infinity for Hegel, and love and mercy for Camus and Christ.

The theoretical work wasn't just contained in a world of ideas. It helped me make sense of all my social work experience which had been informed, for many years, by spiritual practices such as meditation and yoga. Without any intention on my part, I gradually came to question those early, atheistic versions of existential thought that assumed, a priori, that only the finite material world exists. This is how I came to read existential thinkers like Gabriel Marcel, of whom I knew nothing before I began this thesis.

\section{Focus groups}

I obtained ethics approval to facilitate four focus groups, using digital technology to bring together experienced social workers who had expressed an interest in existentially-informed social work practice. The recruitment for the focus groups was conducted through the Australian Association of Social Workers (AASW), which regularly inform its membership of research opportunities, and from my attendance at the Congress for Existential Therapy in 2015 (see Appendix Two for a copy of the AASW advertisement). The focus group ethics approval process went through Deakin University's human research approval process, and also had to be cleared by the AASW research ethics approval process.

The focus group attracted five social worker participants, from the Northern Territory, Queensland, and New South Wales. All of the social workers were very experienced practitioners, aged between 40 and 60, and all except one was then working in a private practice setting. The exception was an agency-based social worker in disability support. Private practitioners are most likely to desire collegiate involvement, given their relatively isolated work compared to social workers in publicly funded agencies. All of the participants had significant interest in existentialism and had a knowledge of, and some practice experience in, existential therapy. I met one of the participants at the London conference. She had begun work as an existential therapist before completing a social work degree.

Private practice social work in Australia is supported by a publicly-funded health system that provides substantial payments to patients for approved professions to provide psychological counselling for designated conditions under a GP-written and -referred mental health plan. This means that the patient first goes to their doctor, who fills out a mental health 
plan report that involves a twenty minute medical consultation. The patient is referred by the doctor to a focused psychological treatment of up to six separate hourly sessions before a medical review and a further four sessions can be approved, bringing the total to ten sessions per year. Medicare reimburses a set amount of the cost of these ten sessions, but there can be a shortfall which must be paid by the patient. Some practices bulk bill patients, which means there are no out of pocket expenses and only the scheduled fee is charged.

This public funding of approved private counselling practitioners means that many people who could not otherwise afford counselling are able to receive it. Social workers, who are required to be AASW members to have appropriate experience in counselling, and to have completed additional training in evidence-based, cognitive behavioural therapy, are approved by the AASW to be mental health plan-accredited social workers and can thus provide these services.

The social worker participant from the Northern Territory had significant practice experience with Aboriginal clients from marginalized backgrounds. She felt an existential approach to social work was consistent with indigenous approaches to the world, especially in terms of the shared emphasis on meaning and being-in-the-world. She had read Donald Krill's work since his earliest articles in the 1970s and had applied them in her own unique version of existential social work practice.

The existential therapist-turned-social worker whom I had met at the London conference had felt very frustrated in social work training before she came across Neil Thompson's work, which really helped her connect her existential therapy training to an existentially informed social work practice. The two other social workers were private practitioners in mental health, one with a specialization in military veterans, and the other with a general practice. They both expressed a keen interest in the existential approach to social work practice.

The sessions were held in video-conferencing rooms at Deakin University using various online technologies. People were connected by Deakin IT staff through conference calls and other online systems such as Skype. I would email my PowerPoint presentations to the participants before each session. At the start of each session, I would make a 20 minute presentation on the topic of the day before opening the sessions up for general discussion and allowing time for at least one of the participants to present a case study, based on their own experiences but anonymized. I assisted some of the participants to disguise their case materials between sessions. I recorded the audio of the sessions, and the case studies were documented. Three of these cases will appear in the soon-to-be-published book. Before 
inclusion in the manuscript, I further disguised the case examples and sent them to the participants for approval. This led to further additional changes aimed at ensuring anonymity. The cases from my own practice were similarly disguised.

These processes are consistent with the requirements of the human ethics approval process. The participants were also asked how they would like to be acknowledged for their contribution to the research in the book's preface. This acknowledgement was not linked to any of the case examples, thus ensuring anonymity, even in situations in which certain clients wanted their cases identified. The cases were all discussed during the focus groups. This discussion was very positive for me and for all the participants, and allowed for feedback to be given on the work done with clients, as well as for reflective practice discussion on things learning from the casework.

I organized the four two-hour focus group sessions around topics drawn from my reading and from the process of writing the book:

- $\quad$ Session 1: What do we mean by existential social work?

- Session 2: The history of existential thinking in social work (covering Ruth Wilkes, David Weiss, Donald Krill, Neil Thompson, Jim Lantz, and Howard Goldstein)

- $\quad$ Session 3: The challenges of existential social work practice (covering existential approaches to assessment and intervention, R. D. Laing, and Irving Yalom and his group work approach to these matters)

- Session 4: The evidence base for existential social work (covering the final topics of the book, as follows: using creativity in existential social work; existential social policy and social movements, and; bringing it all together)

The benefits in facilitating the focus group for me were that it helped me to clarify the difference between existential social work and existential therapy. I also obtained some very useful case studies that expanded the range of case material used in the book. I had a sympathetic audience with whom to explore my views on existential social work practice. It also gave me some insights into how social workers come to have an existential perspective in their practice. A bonus was that it helped me to make a link between existential theory and indigenous perspectives, which includes the importance of a spiritual dimension. 


\section{Marcel and social work}

During my PhD candidature, I wrote an article titled, 'Applying Gabriel Marcel’s Thought in Social Work Practice', which appeared in the inaugural volume of a peer reviewed online American philosophical journal titled Marcel Studies (Griffiths, 2016). Completing this article required me to gain a comprehensive grasp of all of Marcel's work and its previous application in social work practice, mainly through the writing of American social worker and family therapist Jim Lantz. Nobody had previously identified Marcel's work during the First World War as military social work, but that is what he was doing, reuniting missing soldiers with their families. Marcel's social work experience had a profound impact on his philosophy, which shifted from idealism to a concrete existentialism. The overwhelming number of referrals and the immense human needs that he was dealing with have parallels to the current state of public welfare social work practice, particularly in terms of demand. Marcel's emphasis on our presence and availability over functional approaches (that treat people only as a number or claimant) seemed to me to be worth writing about. Marcel is widely identified as the first modern philosopher to use the term "existentialism”, but he is far less well known for it (Joseph and Reynolds, 2011, p. 15).

I found it interesting that Marcel's military social work experience played such a defining role in his mature philosophy of concrete existentialism. The use made by social worker Jim Lantz of Marcel's philosophy in his family therapy and social work practice gave me confidence to write of my own experiences in applying Marcel's concepts to social work. During this period, I made contact with Felicity Joseph, the only Australian philosopher who had written on Marcel's existentialism. I read her thesis and then initiated a brief contact with her via email (Joseph, 2005).

\section{The London conference on existential therapy}

Attending the inaugural World Congress for Existential Psychotherapy, titled 'Freedom, Responsibility and the Meaning of Being', which was held in London from 14 to 17 May, 2015, enabled me to see, in one setting, the breadth and dynamism of the world-wide existential therapy movement (see Appendix One for a detailed report on my involvement).

Existential therapy is a world-wide movement encompassing many culturally diverse approaches. I experienced first-hand the limitations of the "letting being be" philosophy inspired by Heidegger in a seminar in which the leader did little to prevent abusive behaviour by one of the attendees. This experience complemented my reading of Levinas' and Stein’s 
critique of Heidegger's work. In Chapter 1, as I move towards my definition of existential social work, I give an example of the "letting being be" philosophy in the story of the Aboriginal man and his dingo. Heidegger believed that he had erred in trying to define being through the human experience of being, and in his later work placed being at the centre of his philosophy. 'Let being be' became his catch cry to existential therapists in his Zollikon seminars (Heidegger, 2001). In one sense, Heidegger was correct: when we are fully connected with our spirit and environment, we can be fully ourselves and harmless to others. But we live in a world in which people do trespass against each other. Not preventing harmful actions is itself harmful. For Levinas, ethics is first philosophy, meaning that the needs of others must also determine our actions in this world.

\section{The incommensurability of existential thought}

During the confirmation stage of this $\mathrm{PhD}$, I was asked to address the issue of the incommensurability of existential thought. "Incommensurability”, here, refers to the idea that the foundations, assumptions, premises, and arguments of the key existential thinkers are not only inconsistent with but also in opposition to each other. This creates a problem in applying existential thought to social work practice. How can you borrow useful ideas from such a diverse group of thinkers and bundle them together under one label when the premises of their views cannot be reconciled? Would this not result in an eclectic approach to practice in which ideas are applied without a coherent framework?

"Incommensurability" is a concept derived from the philosophy of science. It is sometimes confused with the term "incomparability", which means that two theories cannot be compared with one another. Incommensurability means that the two things being compared lack a common point of reference against which they can both be measured. When people state that existential theories are "incommensurable", they really mean that they are "incomparable", and are suggesting that these theories cannot be compared or combined because the ideas encompassed by the term “existential” are based upon completely different premises or paradigms. In this section, I will argue against that proposition.

A considerable body of secondary literature on existential thought, which began to appear in 1938 and has continued to this day, compares, contrasts and combines the work of existential thinkers, even if the thinkers themselves have rejected the existential label. This literature contains some key findings. Below, I will examine some of the key figures in this secondary literature, such as Hazel Barnes (1959), James Collins (1954), William Barrett 
(1961), Walter Kaufmann (1972) and Kevin Aho (2014). What these key findings might be is not always clear. Perhaps one of existential thought's perennial appeals is its rejection of academic philosophy in favour of real-world experience, meaning, in phenomenological terms, "the things themselves", or a return to our concrete or lived experience. Ideas and ideology are part of this world and not separate from it.

One of the central concepts uniting existential thought is freedom. What makes human beings different from other species is our ability to choose or decide for ourselves. For Sartre, perhaps the existential philosopher most identified with the existentialist label, freedom became the central concept. Our consciousness, he thought, is always directed at objects, but contains no permanent structures within it. Even our so-called egos are constructs which we create and sustain, and which change over time. Our consciousness is in the world, along with the self that we have constructed for ourselves. The modern concept of freedom also preoccupied philosophers like Hegel, who could see the value of this moral ideal but also some of the limitations created by the absence of guidance on its application.

Like Robert Solomon, Maurice Merleau-Ponty and Jon Stewart, I assert that Hegel's absolute idealism has been misinterpreted by early existential thinkers, like Kierkegaard, who reacted against Danish Hegelianism as it was understood at the time. Hegel was not against the individual (Stewart, 2010). These thinkers, Solomon, Merleau-Ponty and Stewart, have argued for a stronger association between existentialism and Hegel's idealism, on the basis that Hegel embraces the modern Kantian advocacy of the value of freedom, but avoids Kant's dualism by describing one dynamic, imminent and transcendent reality, a reality in which we become more real as we become freer.

The missing ethical dimension of the good in existentialism is to be found in Hegel, and in more recent scholarship on him. Robert Wallace (YEAR) is my key source for this view. Merleau-Ponty (1964) argued in 'Hegel's Existentialism' that existentialism has its origins in Hegel's early thought, particularly his Phenomenology of Spirit.

It is well known that Kierkegaard formed his views in opposition to Hegel, although more recent scholarship challenges this view and argues for a more complex relationship involving considerable continuity (Stewart, 2003). What is less well known is how important existential themes, such as freedom and responsibility, practice and lived experience, were to Hegel. I want to argue that these themes are significant in Hegel's more mature, idealist writings, in which his focus was on real freedom, and on how traditional and modern individuality could be reconciled, as well as on how transcendence takes place within concrete existence. 
I think that returning to Hegel as an existentialist precursor is one way in which existential social work can connect to critical social work theory. By this I mean that the social change function of social work practice is aided by having a critical perspective on its current form. Hegel provides a dialectical historical perspective that seeks to transform the world through ideas. The social change function embraced by the critical school of social work is not an optional extra but a necessary part of an existential approach to social work practice.

I am using Hegel's theory of the three elements of the concept here, namely the singular, the particular, and the universal. Existentialism, as a concept, contains these three elements, and they are a useful way to describe how a broad critical existential approach to social work can be constructed. Again, this idea of the three elements in an existential concept comes directly from Hegel.

In existentialism, there are broad unifying themes that seem to be universal, like freedom and responsibility, authenticity, and lived experience. Below that level, there are particular existential theories, for example, Sartre's work on social movements from the 1960s, which is sometimes described as social existentialism and is contrasted with his more early individualistic ethics. Finally, there are singular theoretical elements linked to existential theorists that reflect their unique perspectives, such as Camus' (2000) concept of calculated culpability, the idea that in choosing a lesser evil we must acknowledge it is still evil and cannot be equated with the good.

I am applying existential thought to social work practice. This purpose shapes the way I explore this field of thought. For example, much of the literary existential writing is not applicable to my purpose - even though it is probably the most popular aspect of existential writing - unless it explores a particularly relevant subject. In other words, I am refusing to restrict my selections simply because their assumptions are not comparable. In social work, we use combinations of methods from different theoretical approaches, such as cognitive behavioural therapy, in which we separate thinking and feeling processes and show people how changing their thinking processes can change their behaviour. From a post-modern narrative therapy perspective, I might use art therapy to encourage clients to select pictures that represent their family of origin and the family they want now and to tell a story about that as a way for them to construct a new storyline for their future lives, separated from the dominant narrative of their childhood.

I would argue that the alleged incomparability of existential thinkers is over-stated. Consider the following point: most of these existential thinkers have thoroughly read and 
absorbed other leading existential thinkers. For example, Sartre read Kierkegaard, Husserl, Heidegger and Hegel, amongst many other related theorists. When you read Sartre, those influences are obvious. You cannot really read Sartre's philosophy without some understanding of these philosophers, particularly Hegel. Sartre also added new ideas to existential thought, with regard to ethics and personal responsibilities. I am not the first social worker to argue that there is coherence within existential thought. Neil Thompson (1992), while certainly expressing a preference for Sartre's social existential approach, has also written about other existential writers, such as Nietzsche (Thompson, 2008).

The next section of this exegesis provides an example of an occasion when Sartre drew upon his reading of Heidegger's work on truth to advance his own views on the subject.

\section{How Sartre read Heidegger}

In this section I wish to address the incommensurability argument by looking carefully at how the two key existential thinkers developed their understandings of truth. In 1948, Sartre is at the peak of his popularity in France, having become a prolific writer. He takes time out of his busy schedule to read Heidegger's Essence of Truth, which was published in Paris that year. Heidegger's book (1988) was based on a series of lectures he gave in 1931-32, which drew on writings by Plato. In this work, Heidegger argues that the original meaning of truth was "un-concealment", before it became truth as “correctness” or “correspondence”. He argues that the latter concept, which had come to dominate western thought, is derivative from the older concept of truth. Heidegger is arguing that the essence of truth is not some static notion, but an occurrence in which the human being is actively participating. Being likes to remain hidden, and it requires the human to comport herself or himself towards it and actively engage with it for the un-concealment to take place. Heidegger's intent here is to expose the whole of western philosophy as having been misguided by a derivative version of the truth. He claims to have discovered a more primordial version of the truth that had been forgotten for the last 2,000 years. He does not argue against truth as correspondence, only that it is secondary to the primary understanding.

It is well known that Sartre read Being and Time by Martin Heidegger before writing his Being and Nothingness and that he was heavily influenced by that work. In 1948, reading Heidegger's latest work, Sartre appropriates Heidegger's insight into truth as "unconcealment”, but for Sartre it is humans that unveil being or truth or refuse to unveil it. The main theme of Sartre's work is ignorance, which he regards as an intentional act. 
To put his argument in a social work context, one could imagine three characteristic modes of operating in ignorance of the truth in doing a social work job. The first mode might be described as a state of ignorance in innocence. Here, the social worker just wants to "get on with the job”. He or she doesn't want to investigate the truth, but just to get through the day as easily as possible, doing only what is required. We can all feel this way, especially when we are overwhelmed with demands and there is nothing we can do about it but get through the work as painlessly as possible. We are passive towards the truth. Sartre would say we are washing our hands of the truth. The second mode is a kind of passive contemplation. Here, we simply follow the policy and guidelines as set down by others, as if the truth has already been given - "this is the way business is conducted around here". Sartre would say we hide ourselves from our own responsibility to make the truth exist. This is our fate; we simply put up with everything. Finally, there can be the use of abstraction as ignorance. Here we find social work theorists who write abstractly about social work, without any connection to actual practice, only to conceptual truths.

Sartre argues that for being or truth to appear we have to go and find it. It is often suggested that Sartre's writing in Truth and Existence misconstrues Heidegger, in that in Heidegger's thought it is being that unveils itself - but that is far from Heidegger's actual writing on this matter. Here is Heidegger, using Plato's allegory of the cave, on the third stage, when humanity has escaped from the cave and is in the light of the sun:

'The genuine liberation does not only depend on an act of violence, but requires persistence and courage to endure the individual stages of adaptation to the light, the strident courage that can also wait, that is not deterred by reversals, that knows that in all genuine becoming and growing, no stage can be leapt over, that empty busyness is just as useless and disastrous as blind enthusiasm' (Heidegger, 2002, p. 33).

This is hardly a meditative approach to letting being be. Sartre embraced Heidegger's text and adapted it to his purposes; this is the foundation of Sartre's version of truth in freedom:

'Thus man [sic] can choose no-truth. This non-truth is ignorance or lie...Unveiling implies that what is unveiled is originally veiled. Subjectively, this means that man's condition is originally ignorance. Finally, the unveiling behaviour is activity. To allow being to appear as it is, we have to go and look for it' (Sartre, 1992, p. 13). 
Sartre never sought to publish this work during his lifetime, as he followed his own advice in finding the truth for himself. He had already uncovered a new social existentialism by combining Marxist thought with existentialism in the post-war period. Truth and Existence was only published in 1989, nine years after Sartre's death. In 1948, Sartre was focused on rebuilding existentialism on a redeveloped and rethought Marxist philosophy, informed also by Freud and existential biography, but he took the time to read Heidegger's new work and was obviously inspired enough to write his response. There is far more that is commensurable between the two works than is incommensurable. Truth and Existence shows existentialism at work, Sartre building upon Heidegger, perhaps with different purposes in mind, and yet both illuminate some aspect of truth that is not found in other works.

I am not saying I agree with either author. Sartre’s concept is too human-determined, Heidegger places the initiative with being itself and with our comportment towards it. I have concerns about Heidegger's statement on violence in un-concealment, as mentioned in the excerpt above. I think there is an ethical component in truth seeking that requires relating to others in non-harmful ways, which neither author mentions. But my purpose here was not to assess these thinkers' work, but simply to show how closely they relate to one another. 


\section{Being-in-the-world}

All existential thought shares a fundamental belief in challenging the subject-object divide created by Cartesian thought. This is the existential concept of being-in-the-world (Heidegger), person-in-the-world (Stein, Marcel), or life-world (Husserl).

While there are subtle differences between these concepts, they share an existential phenomenological unity: our consciousness is in the world, and not separate from it. We are beings who are open to the world. We cannot pretend to stand outside the world and observe it objectively, as if our presence and observation does not affect the things we are observing. This stands in opposition to the empirical view (i.e. that the external world of facts is independent of consciousness), and to the scientistic view that the only reality or real truth is that which is studied objectively through the natural sciences or equivalent methods. It also stands in opposition to idealism, (the view that ideas create the world, and not the other way around), often associated with spiritual perspectives; for example, that all reality is maya or illusion, or that it is just a figment of our imagination - among the categories of existential philosophy, only Buddhist existentialism proposes that the world is illusory (Millar, 2008).

We participate in the world through the interaction of our bodies, minds and spirits. Atheistic existential thought tends to be closed, a priori, to the idea that a non-material spirit world exists; proponents of this view choose to close themselves off from the spiritual. The atheistic existential view is as much a belief as is the belief in a spiritual world. An existential view that is more open to spiritual phenomena need not be theistic, because that term connotes a belief in a superior being. Like many indigenous belief systems, existential thought can include a belief in or openness to more than the finite or material aspects of the world. These non-material aspects of reality include the ethical, the mythological, the emotional, and the mysterious. These things are as much in the world as the more obvious material things. But spiritually inclined existential thinkers can still gain a lot by reading atheistic philosophers such as Sartre and de Beauvoir, simply because their insights into the concrete world are so significant - they just need to bear in mind that their a priori refusal to accept the spirit world limits the scope of their thought on such matters.

The fact of our being as a part of the world entails interconnection and interdependence with the world. It is incumbent upon us to act in the world to make it a better place. Thus we must create ethical priorities for our fragile and vulnerable finite lives (as found in the "face of the other"), and challenge the technological trends that treat humans and animals as things to be used, as "standing reserve" and only of instrumental value. The existential nature of 
social work necessitates this, based on our commitments to ourselves and others, including to other animals and the environment. Much of what we do in social work is based on this unconditional concern, these "musts" which are built upon our committed practice. A critical social worker, for example, is committed to social change and transformation towards social justice. This is not a matter of commitment. It is this deeper personal meaning in social work that is the focus of an existential view. Robyn Miller provides a powerful example of this meaning when she describes using a narrative approach to connect with a male client's pain as "his story", only to be told by the client that 'love, that's not my story, it's my life' (Miller, 2016, p. 145). As the American existential writer Bugbee (1961) states, it is based on a relationship to ourselves, revealed from our concrete lived experiences, from which we discover our commitments, the things we must do.

Discovering this lesser known spiritual version of existentialism helped me to find my perspective within existential thought. I was particularly struck by the work of William Luijpen (1960) on existential phenomenology, which argued that there is a core element of the existential phenomenological outlook that takes in the work of Merleau-Ponty, Heidegger, Sartre, and Marcel. This is the concept of being-in-the-world which I have discussed above. Learning how existential thought progressed throughout the $20^{\text {th }}$ century also brought light to my search. I discovered that Levinas was there at the very beginning of Sartre's study of Husserl's phenomenology with his early work, The Theory of Intuition in Husserl's Phenomenology (1991).

After the Second World War, Levinas' writing is a deep reflection on and critique of the flaws and limitations of Heidegger's obsession with being, which Heidegger regarded as the most neglected and misunderstood concept in the history of western thought. I also discovered Edith Stein's (2007) previously unpublished review and comments on Heidegger's Being and Time, and her work helped me appreciate her profoundness, in spite of her being largely neglected as an existential philosopher. Both Levinas and Stein, by adding a viewpoint different from the more atheistic existentialism of Heidegger or Sartre, helped me to write Chapter 1. 


\section{Incommensurability and lessons from the secondary literature}

The secondary literature adds to the argument that there is a collection of distinct but connected views that express the existential position. The secondary literature mentioned above includes critics of existentialism, such as Collins (1962) and Kaufmann (1973), and advocates such as Barnes $(1959,1977)$ and Barrett $(1956,1961)$. The selection of works discussed here was published over a span of more than 50 years, between 1959 and 2014.

\section{Hazel Barnes}

In Hazel Barnes' autobiography The Story I Tell Myself (1997), she discusses the background to her first book, The Literature of Possibility: A Study in Humanistic Existentialism, which she wrote after translating Sartre's Being and Nothingness for its first English language edition. In her book, Barnes synthesises the literary thought of Albert Camus, Simone de Beauvoir, and Jean Paul Sartre. Camus and Sartre had already had a very pubic falling out, and Camus had disavowed the label existentialist. In her autobiography, Barnes published a letter she had written to Camus and his reply. In her letter to Camus, Barnes apologies for describing Camus as an existentialist and comments that Camus' insights often completed or developed more fully the views of Sartre and de Beauvoir. Camus, in reply, states that he preferred the title 'existential writer' (Barnes, 1997, p. 160). This is not merely of historical interest; here Barnes is supplementing the existentialism of Sartre and de Beauvoir with the existential writing of Camus. Similarly, I have adopted Camus designation and titled my work 'The Challenge of Existential Social Work Practice' in line with Camus' response to Barnes.

Social work writer Neil Thompson makes a distinction between existentialist writing on social work, which he claims involves the application of Sartre's Marxist existentialism to social work, and the "existential” in social work, which he argues covers too broad a range, because lots of issues in social work could be considered "existential”. While it is true that the word "existential" embraces a broader range of writing than does the label existentialist (Aho, 2014), it is not the case that all social work writing is existential. There is a lot of abstract writing in social work that is not related to concrete practice, nor to the lived experience of social workers and their clients. Like Camus, however, I have chosen the word “existential” over Thompson's “existentialist” to entail a broader range of approaches to existential thought than Sartre, and to focus on the concrete lived experience of social work practice. 
This approach allows me to describe Jane Hoey as an existential administrator on the basis of her ethical and professional stance on social policy and administration. Jane Hoey was the first Director of the United States Bureau of Public Assistance and her story is told in Chapter five of the book. It enables me to provide an alternative view to Thompson on existential social work, a view that is not restricted to social work informed by existentialism, but which expresses an existential viewpoint that could almost be described as the "inner lived experience” of social work. Thompson attempts to understand social work from an existing existentialist theoretical perspective, as first described by Sartre. I am basing my existential approach on the concrete necessities of social work practice, an approach based partly on our lived experience of social work, and on the revealed meanings, values and understandings gained from this experience, including existential ones.

Barnes never read Heidegger. She and I experienced a similar aversion, based on his association with Nazism. Her existentialism came close to the atheism of Sartre's, although in her autobiography she admits that she found his approach to human relationships somewhat aloof and cold. Her inclusion of Camus and de Beauvoir aims to correct the flaws or limitations she had found in aspects of Sartre. She called this new philosophy 'humanistic existentialism'. This is curious, because in the USA existential therapy is also often associated with these ideas, being described as "humanist existential therapy", which combines the client-centred approach of Rogers (1980) with the existential therapy of Yalom (1980), May (1950) and others. Here is Barnes description of humanistic existentialism:

'The concept of the absurdity of existence, the concern to justify man's [sic] resolve to live meaningfully in the face of an indifferent universe, the philosophical analysis of the basis of human solidarity, the ideas of authenticity and bad faith, the refusal to accept a society based on the assumption of absolute good and evil, a sympathy for those scapegoats who are sacrificed to social expediency, a feeling for the absolute value of the individual combined with the recognition that one cannot today live wholly innocently-all this based on an explicit or implied psychology which holds that every man is free but that we are all responsible for the situation within which a freedom must choose itself’ (Barnes, 1959, p. 376).

While her book is restricted to the three writers mentioned, Barnes remarks that in her public lectures she always constructed her talks around Paul Tillich's triad of basic anxieties that all humans experience in the face of our finitude, as set out in his book The Courage to $B e$ (2000). These three basic anxieties are of fate and death, of emptiness and meaninglessness, and of guilt and condemnation. Much of human life is devoted to avoiding 
the despair engendered by these anxieties. Tillich wrote his book while supervising Rollo May's PhD, which was eventually published in book form in The Meaning of Anxiety (1950). Tillich had May read everything ever published on anxiety, but the two writers who most strongly shaped his work were Kierkegaard, particularly his The Concept of Anxiety (first published in 1844), and Freud. Tillich was inspired by May's work, and particularly by the idea of the necessity of courage in the face of anxiety, to write The Courage to Be. I mention this anecdote of relationships of influence to demonstrate how close the links are across existential thought over the past two centuries. Barnes' book was one of the first attempts to draw together a common viewpoint from amongst the key, but until then seemingly disparate, existential writers. Barnes' writings and friendship with Betty Cannon would result in the latter writing her book Sartre and Psychoanalysis (1991), which argues for an existential psychodynamic therapy framework.

\section{William Barrett}

William Barrett introduced existentialism to the reading public of America in his bestseller Irrational Man (1958), which argued from the premise that existentialism's popularity reflected a deep dissatisfaction with academic linguistic philosophy and its sense of detachment from real life. He captures the mood of existential thinking and the unifying themes addressed by existential thinkers:

'People do die, people struggle all their lives between the demands of real and counterfeit selves, and we do live in an age in which neurotic anxiety has mounted out of all proportion so that even minds inclined to believe that all problems can be solved by physical techniques begin to label 'mental health' as the first of our public problems’ (Barrett, 1958, p. 9).

It was this attention to the concrete issues affecting all lives and society as a whole, as opposed to the abstract approach taken by academic philosophy, which attracted people to existentialism. These concrete issues were always obvious or immediately present; they had to be investigated. Here is Jean Wahl from his 1932 book Towards the Concrete, one of the first works to address existential thought:

'The concrete is never the given; it is pursued. It is not in the absence of thought that the concrete can reveal itself to us. This is what the young Hegel sensed and many poets as well. A dialectic is necessary precisely because there is a realism here. The 
real is the limit of the dialectic. It is its origin, its end, its explanation and its destruction’ (Wahl, cited in Flynn, 2006, p. 356).

Wahl is assuming agreement about reality, but he is also saying that the existential view will not end with a well-constructed, abstract, illuminating theory, such as that developed by Hegel. Principles can guide our behaviour, but there is always this moment - experience, client, group, social movement - that is happening right now, that needs attention and focus. There is always the concrete. Similarly, in Irrational Man, Barrett (1958) critiques the other major alternative to existentialism, Marxist humanism, for its failure to account for the 'thoroughly problematic nature of man, this highly questionable and self-questioning animal' (p. 273). Barrett (1958) argues that the actual experience of communist movements, in their quest for power rather than the transformation of humanity, owes more to Nietzsche than to Marx. Barrett defined existentialism as:

'a philosophy that confronts the human situation in its totality to ask what the basic conditions of human existence are and how man can establish his own meaning out of these conditions. Its method is to begin with this human existence as a fact without any readymade pre-conceptions about the essence of man. There is no prefabricated human nature that freezes human possibilities into a pre-ordained mould. On the contrary man exists first and makes himself what he is out of the conditions into which he is thrown. "Existence precedes essence” as the formula puts it' (Barrett, 1956, p. 127).

\section{Walter Kaufmann}

Walter Kaufmann (1956) argues that existentialism is 'not a philosophy but a label' (p. 11). After documenting the range and diversity of views that fall within that label, Kaufmann (1972) asserts that the primary binding element is the 'refusal to belong to any school of thought, the repudiation of any body of beliefs whatever, and especially of systems and a marked dissatisfaction with traditional philosophy as superficial, academic and remote from life - that is the heart of existentialism' (p. 12). He critiques the existentialists for their failure to remain true to their value of freedom. Kaufmann maintains that the existentialists could not live with their extreme subjectivism, which seemed to imply a moral anarchy; the rationalist ego can maintain a view that now anything goes. How do we insist on responsible decision making? The existentialists have various responses to that question, but Kaufmann (1973) argues that they have invariably been forced address what he calls “decidophopia”, or the fear 
of autonomy. He states that choosing responsibly means weighing alternatives, and here Kaufmann, like the existentialists, is focusing on major decisions that give shape to your life. Kaufmann clearly has in mind Sartre's concept of bad faith, which focuses on the human tendency to act as if you are not free. Kaufmann lists five strategies people use to escape from autonomy:

1. Adherence to religion/authority/a school of thought/a social movement. This is four strategies rolled into one, but they appear to amount to the same thing: we make a decision (for example, I am going to be an existentialist), and then all decisions in my life flow from the consequent subservience to the chosen authority. Kaufmann describes this as the most common strategy, and the trouble with it is that very few such forms of authority can withstand the constant change involved in modernity - most eventually show evidence of disintegration. In choosing a school of thought, our basic decisions have been made, and thus some things have become an unquestioned framework. Now, only the smaller choices are required of us. Rival schools of thought are ignored. Kaufmann describes this as micro-scopism, and he gives an example; when Sartre adopted Marxism as his philosophy: 'Everything we established in The Problem of Method follows from our fundamental agreement with historical materialism,' writes Sartre (2004, p. 15).

2. Drifting. This consists of two alternatives: adherence to "status-quo-ism", which is just following mainstream views without much thought, and becoming a drop-out, someone who lives for the moment without any ties, traditions, code, or purpose, leaving things to change on their own. Kaufmann mentions Meursault in Camus' The Stranger as an archetypal drop-out drifter.

3. Exegetical thinking. Here the authority of a text becomes your own through your analysis of it - the text becomes your authority. Your interpretation of the text enables you to be an authority. Kaufmann points to Heidegger's dismissal of the whole of western philosophy, before the maturation of his thought in Being and Time, and to his embrace of pre-Socratic thought (which is fragmented and open to diverse interpretations), by which he read his own interpretation into the texts. The same happens with Holderin's poetry in the later Heidegger's obsession with being as the sole source of meaning and his rejection of philosophy as a method through which being can be disclosed.

4. Manichaeism. A situation in which a decision is not required, because the decision is loaded by black and white thinking. Inconvenient facts are ignored, history is falsified, uncomfortable arguments are discredited. Heidegger's definitions of authenticity and 
inauthenticity are couched in this contrasting way; but a person can be resolutely authentic and support dishonest, inauthentic social movements, like fascism.

5. Moral rationalism. Kaufmann describes this as evasion of autonomy by arguing that all that matters is rationality or logic. The opposite is moral irrationalism, when rational matters are considered completely irrelevant to key decisions, as some existential thinkers like Kierkegaard and Heidegger have maintained. Kaufmann supports neither position.

Kaufmann also lists other strategies for avoiding autonomy, such as pedantry, which is a form of creeping micro-scopism, marriage as a "committee of two", and finally trendyism, or following the "wave of the future", as Sartre did when he described Marxism as the ‘philosophy for our time’ (Kaufmann, 1973, p. 26). After Kaufmann’s analysis, I am left wondering what is left of autonomy. Perhaps it is a myth.

All these criticisms assume that deciding is something we do in some completely isolated bubble, beyond the influence of the world. Other writers must surely influence our views. We are all shaped by social movements and ideologies. I reject Kaufmann’s criticisms of Sartre and other existential thinkers. There is a harshness to his writing, which reflects bitterness at his assigned role of conservative critic of existential thought. I also think he is wrong to argue that existentialism rejects all systematic thinking. As I have already stated, Sartre, for example, studied many other writers, including Bergson, Husserl, Heidegger, Hegel, and later Marx, before developing his own ideas. Kaufmann's (1973) uncritical advocacy of Solzhenitsyn as an exemplar of autonomy, who supported Putin's earlier claims on the Ukraine in the name of pan-Slavism and a return to imperial Russia, demonstrates what unreflective criticism can miss in its focus on condemnation.

\section{James Collins}

Perhaps no other secondary source has had more influence on my thinking than my tattered paperback copy of James Collin’s Existentialism, published in early 1952, and bought from a second-hand bookshop for two dollars. Collins is specific about his perspective. His critical approach is to weigh existentialism from the viewpoint of theism and realism, informed by the Catholic saints Augustine and Aquinas. His work is very scholarly, and he summarizes the essence of the key existential thinkers Sartre, Jaspers, Marcel, and Heidegger. I went on to buy other books by Collins, including a 1962 book which contained the first English 
language summary of the work of Edith Stein. His stance as a theist is unique among secondary commentators, because he seems to appreciate that existentialism's rejection of God and its atheistic phase were an essential part of its journey into the limelight during its adolescence in the 1950s. Collins summarizes his view about existentialism's future in a way that seems to resonate with my views on its popular phase:

'Either under their own power or in alliance with an existential metaphysics of the infinite and the finite modes of being, the existentialists will have to reconsider their major themes, now that the first outlines have been sketched' (Collins, 1952, p. 251).

\section{Kevin Aho}

I have already commented on Aho's introductory text Existentialism (2014), but I would add that his explanation of the core elements of the existential outlook is consistent with what I have written above, particularly the central concept of being-in-the-world. Aho's text also includes up-to-date connections between Buddhist thought and existential concepts, relating letting go of attachments and suffering to their impact on our health. He is also aware of the now-global reach of existential thought, and of its continued relevance in fighting oppression through critical existential perspectives (Matustik, 1993), as well as of black (Gordon, 1997; O’Bassey, 2007; Gordon, 2008) and feminist existential writing (Welsh, 2015). Aho is also very aware of the diverse impacts of existential thinking on therapy and mental illness. Aho ultimately sides with the limited atheistic perspective in describing existentialism through literary studies that emphasized the limitations and struggle of finite existence, and the loss of any absolutes, leading to the need for self-creation of meaning. I explore the links between existential and critical social work later in this exegesis. 


\section{Categorizing Existential thought}

Existential thought has been classified in various ways. There is the traditional classification of atheistic versus religious, which was first publicly expressed by Sartre in his famous impromptu talk 'Existentialism is a Humanism' (2007).

Table 1. Existentialists Categorized According to Belief in God

\begin{tabular}{cc}
\hline Atheist & Religious \\
\hline Heidegger & Kierkegaard \\
\hline Nietzsche & Jaspers \\
\hline Sartre & Marcel \\
\hline Camus & Hegel \\
\hline De Beauvoir & Buber
\end{tabular}

The problem with this classification is that there is as much difference within the categories as between them, so other methods of classification have been tried, such as a hermeneutic comparison between the monological or strict existentialists, who are supposed to be exclusively focused on the individual, and the dialogical existentialists who are antiCartesian, along the lines of Heidegger's critique of Sartre (see Table 2, below.

Table 2. Existentialists Categorized Hermeneutically

\begin{tabular}{|c|c|}
\hline $\begin{array}{l}\text { Early, Cartesian, Monological, } \\
\text { "Individual" Existentialism }\end{array}$ & $\begin{array}{c}\text { Later, Dialogical, Anti-Cartesian, } \\
\text { hermeneutic, and social existentialism }\end{array}$ \\
\hline Nietzsche & Buber \\
\hline Early Sartre & Heidegger \\
\hline Camus & $\begin{array}{l}\text { Later Sartre (Marxist and post-Marxist } \\
\text { phase) }\end{array}$ \\
\hline Kierkegaard & Jaspers \\
\hline Dostoevsky & Merleau-Ponty \\
\hline Kafka & Marcel \\
\hline
\end{tabular}


Clearly this division favours the dialogical hermeneutic version of existentialism, which is based on Hegel and Heidegger. These thinkers shared a concern for the relational, but there are substantial differences between their approaches, so this split remains problematic. Similarly, theorists also find problems in the splitting of Sartre's earlier and later thought.

There is no denying that there are significant differences amongst the key existential thinkers. However, they do share common concerns, and one of these is the view of existential thought as a way of life or social movement. This is reflected in their ethical concerns, emphasis on the concrete or real, and a return to a meaningful philosophy that affects how we live and work. In this view, existential thought is heir to the original Socratic/Platonic view, in which philosophy guided decisions, actions, and way of life.

As I have already described, existential phenomenology - a viewpoint shared by Marcel, Sartre, Heidegger, Merleau-Ponty and others - does have an illuminating unity around the fundamental concept of our existence as beings-in-the-world. What creates divergence between these scholars is that some were committed atheists, such as Heidegger, Merleau-Ponty and Sartre, who rejected a priori the existence of a supreme being. Others, such as Marcel, were theists. I have previously stated that belief in a supreme being is not a necessary condition for a belief that the world contains more than the finite.

\section{What is existential social work practice?}

Frederic Reamer, in The Philosophical Foundations of Social Work (1993), acknowledges a failure to address the philosophies of religion and existentialism in social work. I was surprised by this failure, and by the marginal status given to existential thought, particularly as I was aware of how influenced Neil Thompson had been by existentialism, how underpinned by existentialism were his popular works, and how little attention was paid to existential theory in social work theory courses. Paradoxically, existential therapy was thriving both as a kind of meta-theory for therapists, allowing them to use other theories within an overarching existential framework, and in specific schools of existential therapy, such as those influenced by European Dasein analysis using Heideggerian thought and phenomenology (Cohn, 2002), philosophical approaches (Van Deurzen, 2010) and logotherapy (Guttmann, 1996). I was also interested in closely aligned schools of thought, such as the short-lived, but highly influential, approach of David Brandon (1979) in creative social work practice. 
In studying Hegel's Science of Logic with a Marxist reading group, I became aware of how closely existentialism had evolved with, sometimes in response to, and also from, Hegel's absolute idealism. I was studying Hegel within the context of his value for understanding social movements and the split between the social and the individual. I have used his theory of the singular, particular and universal parts of concepts to describe how existential social work should be conceived (see Figure 2, below).

\section{Figure 2. The Singular, Particular and Universal Elements of Existential Social Work}

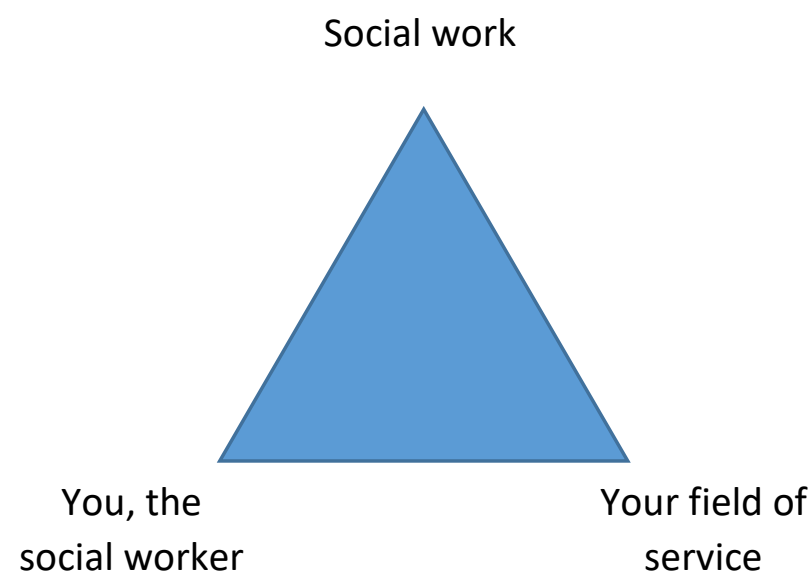

In the first chapter of the book, I define existential social work practice as focusing:

'on the lived relational existence of people, which is always more than any amount of thought can explain. It aims to support people to create their infinite potential in the concrete world. An existential approach aims to create safe and peaceful spaces for client and worker growth, to prevent further harm and to enhance positive change processes. An existential approach creates this space, even in social control situations where statutory obligations are in force.

Being is difficult to describe, but perhaps this is where existential thought aims to create an experience of being fully alive, or of a more abundant life for ourselves and our clients. Social workers’ and our clients’ beings are threatened by external forces, such as technology, global warming, our own fallibility, frailty and death, the slow malaise of loss of purpose and meaning, and negative emotions, including rejection of self and others, and loss of destiny and identity.

Existential social work acknowledges the oppressive circumstances of clients' lives and how this shapes and determines their decision making and coping abilities. It aims to strengthen their abilities to grow, despite this 
oppression, and helps them take responsibility for shaping their own lives. To do this effectively requires the social worker to take responsibility, as a professional helper, for their own growth and development, and to live their life to the fullest extent (Taft, 1928)' (Griffiths, forthcoming).

Referring back to Figure 2, above, I wanted to incorporate a number of ideas from existential thought that I considered valuable in describing practice. The first is that practice must involve the person - the critical reflective social worker, the singular or subject - as a unique person. Secondly, it cannot be objectified separately from the people delivering and clients receiving services in the context of a field of service (such as, say, child protection). How is existential social work practice applied in child protection with all its policies and procedures, risk management strategies, and other onerous responsibilities? These are the particular aspects of where you are practising social work in historical time, in a field of service. Thirdly, as a social worker, you represent the profession. This is the universal aspect of the concept of existential social work practice, in the sense that it applies to the profession as a whole. What aspects of existential social work practice apply to all fields of service and all individual social workers?

In relation to the universal aspect, Paul Tillich (1962) describes social work as addressing human insufficiency in every unique situation. We listen sensitively and respond spontaneously to the concrete circumstances. As social workers we pursue program objectives, but we also respond to the uniqueness, to the cry within the situation, instead of imposing our agenda. Of course we compare each case with others, but we notice the incomparable and the unique aspects, too. We use empirical and participatory knowledge, and being is revealed through creating the conditions for growth - under which the social worker creates boundaries, safety, respect and a sense of place. That is why social work is more than evidence-based practice; it has spiritual, social and ethical dimensions. 
The empirical in existential social work

Table 3. The Place of Empiricism in Social Work

\begin{tabular}{|c|c|c|}
\hline Clients & Intervention & Outcomes \\
\hline The lived experience & The lived experience & The lived experience \\
\hline \multirow{5}{*}{$\begin{array}{l}\text { Are we comparing similar } \\
\text { cases? Are their } \\
\text { structural/cultural } \\
\text { circumstances similar? }\end{array}$} & Vagueness/Differences & Outputs and Outcomes \\
\hline & Goals of intervention. & \multirow{4}{*}{$\begin{array}{l}\text { Unintended/Unanticipated } \\
\text { impacts. }\end{array}$} \\
\hline & What actual service did the & \\
\hline & client get? & \\
\hline & Why not something else? & \\
\hline
\end{tabular}

The table above suggests that an existential account of social work practice would include the lived experience of the clients before, during and after the social work intervention. This account would insist on fair comparisons of cases by looking carefully at the PCS model (Thompson, 2006) of the client's facticity or social circumstances. Interventions are often vaguely described, and it is unclear, because of this, exactly what the client received. Why did they get this service and not another? Is it because it was the only one available? Would another service have been more appropriate? Can we attribute the outcomes to the intervention, or were other factors influencing the cases? Does the program logic reflect the lived experiences of the clients, or is it other things that are really valued and influencing the outcomes?

An existential approach is not in opposition to empirical social work or evidence-based practice; it wants all the evidence presented, including the mysterious; the fact that I am involved in this particular situation and am not some (illusory) objective observer. An existential approach goes beyond evidence to search for meaning from the participants in their lived experience of the program and its impact on their lives.

\section{Existential and critical social work}

Existential social work, as a critical practice, aims to challenge dominant narratives and structures that oppress others. For example, in my current area of practice, male family violence, there has been significant reform of our understanding of the problem over the past ten years. Public responses to family violence have dramatically altered in both civil and 
criminal law, in police codes of conduct, and in the development of an integrated family violence system in which more information is shared between agencies and limited confidentiality is the norm. While family violence is being challenged, there are still deficiencies in the system. The effort that has gone into legal reform, human service development and police cultural reform (as a result of pressure from activists challenging patriarchy, family violence and abuse, and promoting equality between the genders, and safety in families) should be acknowledged.

At the coalface, this is reflected in men's behaviour change programs which are challenging the embedded power and control stories of the participants, and which aim to change their ways of thinking about members of their families and of ensuring their safety. Many men attending these programs still think that they are the victims. They may be unaware of their entrenched practices of power and control over others. These practices have to be challenged sensitively and spontaneously in a group process, where partners and children are, metaphorically, brought into the room, and the impacts of the men's behaviours are challenged. In addition, the men leave these groups, hopefully, with increased skill in creating safe and peaceful spaces in their family homes in which conflict can be addressed constructively and non-violently.

In facilitating these groups, the group leaders are allowing the participants to be reflective, choice-making people, people who are experiencing imminent challenges aimed at transcending their narrow, self-interested perspectives. In this kind of work, metaphysical issues and beliefs are present in the room. Do I have a right to intervene with this man in this incident at this time? What is the meaning of events for this man or group? As facilitators of these groups, we work with the process to allow the truth about family violence to be revealed. We intend for this to happen, and we construct activities to encourage it to occur, but we cannot make these moments happen. We have to recognize that some men may decide to intentionally remain in ignorance - but we still aim to create the best conditions for their collaboration with the unveiling of truth.

My view is that existential social work is a form of critical social work because it seeks transformation of the kind just described, not just adjustment to or improvement of the system. This work has a vision. It demands a considerable amount from social workers who embrace this approach because it requires a creative awareness of being present and available to every client. It attempts to change lives, to transform outlooks, to seek truth through discovery with clients and to help them take action to transform their circumstances. This is 
not a process in which the social worker has all the answers, but one in which we are in partnership with our clients on a journey of discovery.

\section{Development of each chapter}

In this final section of the exegesis, I comment on the process by which I developed the content of each of the book's eight chapters.

\section{Chapter 1 - Being-in-the-social work-world}

In this chapter, I examine the dawn of existential social work, using elements of Heidegger's approach to existential phenomenology in Being and Time to think through social work from first principles. I have also been influenced by Levinas' and Stein's critique of Heidegger's finite approach to being, and their unique contributions to the study of the question: What does it mean to be a social worker today? During my research, I discovered that Mary Richmond (1922), one of the founders of social casework, had thought through the concept of social casework from first principles using ontological language, like the being of social casework.

Building upon my own direct practice experience in family violence, I attempt to examine the challenges that social work is facing in the $21^{\text {st }}$ century, including increased demand for services, the spread and development of digital technologies, and a loss of purpose and meaning. I examine this phenomenon from the ground up, at the coalface of practice, rather than using the more usual strategy of examining the external forces impinging upon social work practice. I also give a number of practice examples and vignettes designed to challenge students and new social workers to think seriously about their vocation as social workers and what they want to achieve in their social work careers.

\section{Chapter 2 - Immortal social work: The first existential social work practice}

This chapter begins my account of the history of existential thought in social work practice, commencing with the Functional school created by Jessie Taft, who was strongly influenced by Otto Rank, one of the first psycho-analysts and a founder of will therapy.

I have tried to show the creative core of the Functional School, rather than focus on agency function, in the idea of "voluntary acceptance of the obligatory", a phrase made famous by Otto Rank. In social work terms, this phrase refers to the limitations that clients 
need to accept if they are going to effectively use what a particular program has to offer them. A number of social work articles have already linked the Functional School to existential thought, and Otto Rank's biographer also used the phrase to describe his theories. I have made this link more explicit by focusing on the existential elements of Taft's thinking. I am also very much aware that Taft was influenced by pragmatism as well, and by early social interactionism. I use two vignettes in this chapter, both from Taft's work, that I feel exemplify the clarity that she brings to the unique function of the social work task.

\section{Chapter 3 - Existential social work comes of age}

In this chapter, I explore the pioneers of existential thought in social work practice who explicitly identified themselves as existential thinkers, and some who rejected the label but may be described as fellow travellers, such as Ruth Wilkes (1981), on account of their use of existential thought in social work.

I reject the notion that existential thought should give up traditional, core social work and existential values like individualization. I see a trend under which these historical social work concepts are being adopted by management and market forces and are thus being limited to narrow consumerist aims. I argue that existential social workers need to re-assert these values - providing they are combined with a critique of traditional social work's failure to address oppression and to ensure that the uniqueness and lived experience of clients are always addressed in their interventions.

I include two case examples in this chapter to help students identify existential issues when clients are presenting, and to help them question the assumption that western values are necessarily more enlightened than other cultural values that clients might maintain.

\section{Chapter 4-Existential social work assessment and intervention}

Here I examine how an existential approach to assessment and intervention in social work might look in comparison to existential therapy, which tends to de-emphasize assessment and intervention. I argue that it is perfectly consistent with existential theory to use tools and categories to assess people, providing we always understand and acknowledge the limitations of these methods. Individuals are always more than any label placed upon them.

I begin the chapter with an example from R. D. Laing (1971), which makes a crucial point about assessment as a discovery process. I then make use of Yalom's (1980) illustration of an original case by Sigmund Freud (2001), in which he highlights the importance of the 
informal "add-ons" that the worker intuitively initiates in the professional relationship. Yalom sees these add-ons as crucial to effective practice. Closer analysis of Freud's case reveals other complexities to in assessment and intervention, such as the powerful influence of the professional worker on the lay client's understanding of what is happening. While there are both oppressive and caring elements to Freud's case, it also highlights the debt existential thought owes to the psycho-social history of the profession.

I then explore various modern and post-modern approaches, and I continue to argue that the lived experience of assessment and intervention are a vital part of the process and cannot be ignored - agencies and program increasingly prescribe these practices. The social worker plays a critical role in engaging clients and helping them make sense of what is happening. I provide an example of how social work can engage with an LGBTI person, which also illustrates how existential social work differs from existential therapy.

I had hoped to include a section on existential biography and social work assessment in this chapter, but the more I learnt about Sartre's efforts in this area the less I wanted to include this material. I became convinced that his totalization project was fatally flawed in its attempt to completely comprehend another human being using Freudian and Marxist theory. Particularly for social work, our assessments are time- and circumstance-limited documents that cannot wholly enclose another person's life.

\section{Chapter 5 - Existential social work in social policy, social movements and team work}

In this chapter, I examine all the indirect services that social workers are involved in, such as team work, social policy, social movements and policy implementation.

For most of this chapter, I draw upon my own ongoing experience in working in a small family violence team, but also from my social work history in policy, social movements and being involved in a pilot program. I draw upon the concept of "field of service” because it sees significant use in social work practice (Bartlett, 1971). Increasingly, separate programs and agencies are being required to organize their interventions within a field of service, like family violence or child protection, which has collective aims.

The first lived experience for all social workers doing direct practice in the area of indirect service is team work. I provide examples from my own experience in men's behaviour change programs of how you need to do the work in order to find a personal perspective on what you are doing. I describe my own experiences of social movement and 
policy work and of the community work of the Reach organization in Melbourne as an example of successful program implementation.

I then recount the story of Jane Hoey (1953), an existential social administrator and leader who had the courage to stand up to a newly elected Republican president based on her firm understanding of her position as a professional implementer of policy, not a political formulator of it. Hoey had a deep grounding in the social mission of public welfare. Her stance was ethical and based on a creative loyalty to her mission as a social administrator of America's first welfare system. Hoey never used existentialist concepts, but her deep commitment to the social mission of public welfare makes her approach an existential one. This loyalty extended to her refusal to resign or go quietly, which she must have known would result in her dismissal. This stand reflects her knowledge of herself, and her commitment to her profession and the provision of public welfare.

In the next example, I show how social work leadership depends on other elites supporting rather than undermining social objectives. Social work is not a powerful or privileged profession relative to other elite professionals like Doctors and Lawyers. Critical social work tends to ignore the marginal role social work has in determining its social change aims. An existential approach is cognisant of how more powerful professional groupings can undermine social work objectives.

I finish this chapter by looking at the lessons learned from a successful pilot program that was legislated state-wide within ten years. What made the difference when others had failed? Success in social policy and implementation cannot be wholly explained by the project implementation process; something more is required. I use Johnathon Lee's account of radical hope to argue for the role of vision in social work practice, and provide an example of how I have successfully used my visioning skills for program administration.

\section{Chapter 6 - Creative social work and existential social work}

Now I tackle the issue of the role of creativity in social work practice, and what an existential approach might bring to the table. I argue that creativity exists within the limitations of everyday social work practice and that it is what the social worker and the clients brings to the interaction that helps to make the intervention creative. I provide some examples of this creativity in the typical crises that social workers face. I argue that having a strong ethical basis to their practice helps rather than hinders the social worker in being creative - it seems to help the social worker know, a priori, what is unacceptable practice, such as forming a 
friendship with a client, and where the real locus of creativity is: within the limitations of the situation you are facing. I explore David Brandon's (1990) advocacy of a short-lived Zeninspired creative social work, as well as how he was able to contribute to a change in service delivery for homeless people in the United Kingdom. I highlight the role of normal anxiety and the response to it through an exploration of Kierkegaard and Tillich, and of the courage to act despite our fears and worries. I also examine Sartre's notions of worked matter and group-in-fusion to address the inertia and resistance of our bureaucracies to the need for creative change.

Finally, I intended to look at how clients use their creativity to survive and hold onto hope through the story of Leon Jedwab, a survivor of more than one Nazi concentration camp who never gave up hope. In revisions, this story was moved to the appendices because it does not involve social work practice directly, but it remains an example of ways in which hope plays a role in daily survival in even the worst of circumstances. I also removed the details of an example of a creative social worker author who transgressed the ethical boundaries of practice; I decided not to add to his pain and suffering, so the example is talked about only in generalities in the final book. I was able to make the same point using an example from my own experience. In that case, professional boundaries were crossed that could potentially have undermine an agency's access to clients in detention.

\section{Chapter 7 - Evidence-based practice and existential social work}

The existential view argues that lived experience in social work practice is the foundation upon which evidence-based practice (EBP), as a scientific exercise in social research, is practiced. Only a limited range of human experiences tend to count for the purposes of EBP. Much EBP is not relevant to the bulk of public welfare social work, because it assumes a private practice model with motivated clients who attend offices on a regular, weekly basis. When EBP is applied in public welfare settings, it tends to become an additional burden on social workers already dealing with a high degree of structure in the form of procedures, assessment frameworks, and highly prescribed practice methods (Munro, 2008).

I provide an example of how existential social work, while embracing science and EBP, brings more to the encounter with the client. I examine some of the problems I have found in program evaluation using EBP, and how ignorance of these issues can distort outcomes. I examine two of the most famous prospective longitudinal studies ever carried out, and find that they have tended to reinforce an existential point of view that it is how we respond to 
life's challenges through our personal agency that determines our futures rather than our personal circumstances and histories.

An existential viewpoint is wary of the current focus on program outcomes, because it is actually the main element of the program that the social worker has little control over. Failure is an intrinsic part of the lived experience of social welfare programs. To illustrate this point, I provide the example of a whole-of-government strategy that failed to achieve its intended overall aims. I also describe a successful pilot program that came to be legislated state-wide, and I highlight some of the consequences of that success, as well as what is missing from the story if a narrow EBP-focus is used.

\section{Chapter 8 - Conclusion}

The final chapter of the book was intended to be a comprehensive "bringing together" of all the elements of the existential social work approach, using the family violence field of service as an illustration. However, it became more a summation of what I had already covered in the first seven chapters of the book. I end the book with Gisela Konopka (1963) and her two foundational principles of practice, which I believe describe what existential social work practice is all about: that every client counts, and that we need to care about and for each other if we are going to solve the world's problems. This latter idea is clearly different from the self-interested ethic of the market system, which, by definition, cannot meet all needs.

\section{Conclusion}

This exegesis set out to explain the theoretical, biographical and practical manner in which I have come to publish The Challenge of Existential Social Work Practice. I have described how I have come to an existential as opposed to an existentialist approach - one that is more open to mainstream, traditional and critical social work practice. In this approach, I have explored how existential ideas were explored when social casework was in its infancy, how the Functional school embraced the client's creativity within the limits imposed by agencies' purpose, how existentialism as a philosophy helped shape social work, and how existential ideas remain vital in the $21^{\text {st }}$ century and can enhance social work practice.

I have explained how I have come to the views expressed in the book through the use of focus groups, involvement in reading groups, discussions with other authors, and through my own reading of other existential social work writing. My aim has been to express some of the 
richness of this perspective, to share some of the potential dangers or risks, and to offer ways to address these issues in practice.

Ultimately, I have tried to write a text that would be useful to the direct service social worker operating in the large public welfare areas of practice in which most social workers are employed. It is here that they are faced with demand exceeding capacity, highly prescribed practice, and challenging situations. My goal has been to write a text in which these issues are faced directly, and in which a vision of how existential social work can apply in this environment has been set out. 


\section{Appendix $1 \quad$ Conference report}

\section{Details of Conference}

Name of Conference:

Name of Organising Body:

Venue:

Dates of Conference:

Type of Involvement in Conference:

Nature of Presentation:

Title of Presentation:
World Congress for Existential Therapy

New School of Psychotherapy and Counselling

Church House, London, United Kingdom

14 May 2015 to 17 May 2015

Poster Presentation

Recruitment of social worker participants for focus groups being conducted in the second half of 2015 .

'Interested in Existential Social Work Practice?'

\section{Achievement of planned aims and objectives}

The two objectives planned for this conference were to participate in the conference (and thus to be exposed to some of the key writers, therapists and practitioners in existential therapy internationally), and to garner the interest of the attending social workers in the four focus groups that I was to hold in the second half of 2015. My participation in the conference included observing:

- Orah Krug's interview with Irving Yalom (Krug is one of the regular attendees at Yalom's weekly supervision sessions for senior practitioners). Irving Yalom is the most famous contemporary existential therapist. He has written extensively on existential therapy and group therapy. When the clarity of his thought was remarked upon, Yalom said, 'I try very hard never to write about anything I don't understand'. I think this was the most important point in the interview for me, as existential thought can be obscure, obtuse and generally over-complex.

- Keynote speakers Emmy Van Deurzen, a prolific existential therapy writer and a central figure behind the conference, and Kirk Schneider, the current leading figure in the existential-humanist school of existential therapy which is dominant in the USA. Van Deurzen spoke on existential freedom, and Schneider on responsibility and the polarized mind. The conference itself had three themes: freedom, responsibility, and the meaning of being. Alfred Langle, a direct pupil of Viktor Frankl, and a leading figure in the primarily European logotherapy and existential analysis school of existential therapy, 
gave the final keynote address, on the question of existential therapy and the meaning of being. Of all the therapists attending the conference, Alfred Langle seemed to me the most empathic, sensitive, gentle and yet powerful therapist (see also the discussion of his workshop, below).

And attending nine two-hour workshops and symposiums, including:

- Defining Existential Therapy with Emmy van Deurzen, Alfred Langle and US forensic psychologist, Stephen Diamond, who had just completed a chapter of a new academic book on existential therapy in Contemporary Theory and Practice in Counselling and Psychotherapy published by SAGE in April 2015. I spoke with Stephen after this session about his writing process, and I found his comments very enlightening.

- Otto Rank: The First Existential Therapist. This workshop was particularly useful for me, because a discussion of Jessie Taft and the Functional school of social work (which was primarily influenced by Rank) comprises a chapter in my book. Will Wadlington, the primary leader of this session, emailed me after the conference to thank me for my interest, and to express his own interest in my work.

- Love and Existence: An Existential Theory of Love. Some years ago I had read Bo Jacobson's An introduction to existential psychology (2007), and since then I have always wanted to meet this man. His workshop was truly profound, and involved him asking us to share our deepest experiences of love. He then shared with us five theoretical assumptions or points of departure based on his phenomenological understanding of such love experiences.

- Psychotherapy as Ethics: How Ethical is Existential Psychotherapy? Led by Paul McGinley, an existential therapist in private practice, and strongly influenced by Heideggerian thought, I was very keen to participate in this workshop as I have a number of issues concerning Heidegger's ethics. Paul was highlighting some of the ethical dilemmas, such as the expectation placed on the therapist by the client "to know", "to advise”, to have answers, when existential theory actually suggests that there are no answers. This presents an ethical dilemma for the therapist: should they be frank, or, in bad faith, keep their real views to themselves, for the client's benefit? Unfortunately this workshop was usurped by a person who became quite abusive and condescending towards the other participants. He threw some money on the floor to be picked up as a reward by anyone who could answer the ethical questions he was posing. These 
disruptive actions became the session. Eventually, I spoke up, calling this behaviour abusive and violent (for which I was later thanked by many of the participants). However, a couple of the participants maintained that they were not threatened by the behaviour, and so its dominance of the workshop continued. (The man who threw down the money continued to cause problems in other sessions, and his views were quite suspect to say the least.) Although it was disruptive, this situation did demonstrate one aspect of existential thought which I consider to be a limitation - the absence of a strong ethical basis for practice, as Levinas, who rarely gets a mention, pointed out.

- Existentialism and the Transpersonal: What is the Connection? John Rowen led this workshop, and in it he gave a demonstration of his use of the subtle mind that is nurtured by the practice of meditation. I had read many of his books over the years, so I was keen to meet him (Rowan, 1997, 2005, 2010). My Master’s Thesis in social work, 'Teaching Yoga in Addiction Recovery', dealt with the transpersonal in social work, and I was already familiar with Ken Wilber (2010) and his views on the mind's capacity to tap into higher levels of consciousness. Rowen demonstrated this capacity with great acumen with a volunteer, and also laid out the links of such practices to existential thought.

- Social Existential Psychotherapy was run by Cuca Valero, and it was concerned with applying existential therapy "on the streets”, or to social issues, such as in povertystricken communities. I found this workshop extremely inspiring, as it had a social work perspective that went beyond the office. There was nothing especially new in what she had to say, but it was inspiring to see a person living their existential ideas in real life and making no distinctions between environments when deciding how to practice.

- The New Existentialists: Revisioning our being-in-the-world. This workshop was delivered by the developers of the website https://www.saybrook.edu/newexistentialists/, which is based in the USA, but really applies existential thought to current political and social issues around the world. I found that meeting the creators of the website really brought it to life for me.

- A Life Therapy Demonstration. This workshop involved a volunteer from the audience engaging in a therapy session with Alfred Langle. A 65-year-old woman grieving the loss of her life partner volunteered to be the client for this exercise. It was very enlightening to see how Langle stayed with her profound sense of emptiness and desolation without any attempt to solve or move her on from this experience - which was exactly what her friends and other well-meaning people had advised her to try to do. 
- Existentialism in Australia. This session was lead by the Centre for Existential Practice in Sydney. Alison Strasser and Adam Mclean are well known to me, as I have attended a number of their training sessions. In this context, it is important to mention that Strasser's book, written with her late father, Freddie Strasser, Existential Time-Limited Therapy: The Wheel of Existence, is one of the most useful existential therapy books because it deals with the reality of most therapeutic interventions: their short duration.

\section{Academic development}

Attending this conference made me more aware of how diverse the existential therapy movement is and how far it has reached. For example, I had conversations with attendees from Brazil about the popularity of Sartre in Portuguese translation - he represents a significant school of thought in Brazil.

I felt comfortable with this group of people. My skills, knowledge and experiences were comparable with those of the other participants, and this gave me the confidence that what I am writing back here in Australia is going to be valuable in the wider world of social work.

\section{Summary}

I also attended the inaugural meeting of an Australasian existential therapy group from the pacific International Federation of Psychotherapists, with representatives from many Asian countries.

Attending the conference made me aware of the human flaws in some of the leading figures in the existential therapy movement. For example, I observed the mishandling of a conflict over definitions through a simple inability to use basic conflict resolution strategies like agreeing on process before addressing the dispute. There was also a sense of selfaggrandizement in one of the keynote speakers who made a quite unrealistic plea for community-wide therapeutic interventions for all people with "polarized minds", as if existential therapy could cure the world of all its problems.

A key message from the conference was that the existential point of view that anxiety is a benefit not a curse to humanity is central to the existential approach to therapy. (Note that this is not referring to extreme forms of anxiety that can be debilitating.) Anxiety is our teacher. Normal anxiety is actually a help to our growth, not a hindrance. This message goes 
back to Kierkegaard's The Concept of Anxiety, and represents a unique perspective on this universal phenomenon. Rollo May, who published his PhD in book form in The Meaning of Anxiety, also made the same point having undertaken significant research on the subject.

A matter left unresolved for me is ethics, which I feel is an under-developed aspect of existential thought. This issue became acute in the money-throwing incident, as well as when attendees objected to a discussion of evil or the demonic which the forensic psychologist Stephen Diamond brought up in referring to the work of Rollo May. Social work deals with harmful behaviours, and naming these is intrinsic to our psychology, but people from the more open therapeutic world seemed to struggle with this. This difficulty also came out in the silence of the movement on the revelations of the extent of Heidegger's willingness, even after the Second World War had ended, to justify the holocaust using existential theory, arguing, for example, that the Jews have no "being” because they have no homeland. This argument was recently published in the Black Notebooks, which Heidegger expressed no reluctance to publish during his lifetime. I think it is time that the dominance of Heidegger in the existential field is seriously challenged.

Overall, I was inspired by what I saw and heard. There were 1,000 people attending from all over the world. This represents an amazing development of $20^{\text {th }}$ century existential thought, now being implemented as a helping tool in the $21^{\text {st }}$ century. Unlike Mick Cooper, who expressed concern that he was not hearing anything new, I felt that the application of existential thought as presented at the conference would have significant implications for the development of existential theory in the $21^{\text {st }}$ century.

\section{Resulting publications}

Obviously, my book, The Challenge of Existential Social Work Practice, to be published by Palgrave Macmillan in 2017, is the key outcome of my attendance at this conference. I am also required to complete an exegesis and the conference will feature in this publication as well.

\section{Value to my PhD candidature}

It is very hard not to defer to Irving Yalom, who has become a grandfather figure in the existential therapy movement. His amazing writing, which involves advanced storytelling skills, is an inspiration to me. He spoke so clearly on the basics. Without denigrating classic psychodynamic interpretation in resolving life's issues, Yalom stresses the vital importance 
of the therapeutic relationship, supported by the strong evidence he has gathered that clients "take what they will" from the therapeutic experience rather than what the experts think they will. He also backed up his view with the most evidentially sound research conducted in the USA, which demonstrates his point that a close, intimate, genuine relationship is the key to successful intervention. Again, this is not to say that interpretation is not useful, because Yalom emphasized that it is, only that without the other, the relationship, nothing works. Alfred Langle, too, put this point strongly when he said that being means "to really be there as a human being in relationship". You're really here, and then you can "find your responsibility".

Another of Yalom's key messages was that learning and training never end in this business - even at well over 80 , Yalom is still learning!

I also learned that despite existential therapy's growing popularity, it still lacks legitimacy in many countries, and that this could be the fate of my publication unless I address the things that existential thought finds difficult, like evidence-based practice. The potential for further schisms within the existential therapy movement is high. The attendees at the conference could not even agree on a basic definition of what existential therapy is, because of the flawed process they used. A leading existential therapist, Ernest Spinelli, was not invited to the conference because of previous splits within the movement, even though he lives in London. His books were on display for sale, but he was nowhere to be seen.

\section{Recommendation for future attendance and other relevant information}

There were many other matters of significant importance to my work. For example, Robert Kramer's A Psychology of Difference, which includes most of Otto Rank’s lectures given in America, is the best way to understand Rank's work according to Will Wadlington, who presented the workshop on Rank. I was aware of this book but now I am going to read it thoroughly. I had also not appreciated the influence of Nietzsche on Rank.

I discovered, too, that Marcel was a significant influence on Bo Jacobson, as he was for me. Jacobson's approach was to avoid the use of technical terms and to express things simply. This resonated with his audience in the workshop, and I learnt that a similar approach on my part would really improve my book.

I also learned that we need to be realistic about this movement. It is a progressive movement with something unique to offer the world, but it is not a panacea for the world's problems, as some, especially from the USA, seem to think. I remember the frustration of one 
young woman at the conference who is studying existential therapy. She could not understand why people inside the movement fail to appreciate how unknown it is outside it, and that if it is to have any future, it must enter dialogue with the many other progressive movements in the world and become more outgoing and less insular.

At the same time, I was really pleased to meet people at the conference who were using their existential philosophy outside the therapy room to improve social existence more generally, which I see as being akin to my social work agenda. These people included the new existentialists in America, Jacobson's work on love, John Rowan's on making connection with spirituality, the Cuca Valero's application of social existentialism, and a broader feeling within the conference that it was time to engage with the world.

Promoting interest in my focus group study

Deakin University created a poster for me (see attached PDF) which was displayed throughout the conference. The Plain Language Statement and ethics approval memorandum from Deakin University Health were available as handouts. There did not appear to be many social workers attending the conference, but a few came up to me and introduced themselves. I had a number of discussions with a social worker and therapist from Australia and she has expressed interest in participating in the process. By the end of the conference, most of the handouts had been picked up. Whether this will result in finding participants for the research is difficult to tell. I have two other avenues of recruitment approved by the Ethics Committee, but I anticipate that most interest will be from the advertisement to the Australian Association of Social Workers. 


\section{Appendix 2 Focus group advertisement for AASW publications}

The AASW suggests “opportunities for research” to AASW members at http://www.aasw.asn.au/practitioner-resources/opportunities-for-research-participation Title of Research: The Challenge of Existential Social Work Practice

Key dates July-October 2015 (Monday evenings from 6-8 pm, one session per month - exact dates TBD)

Participants Social workers with an interest in and experience of applying existential thought in social work practice (direct service, social action and social policy).

Must have at least five years post-graduate social work experience.

About The aim of the sessions is to obtain eight to ten vignettes that highlight the application of existential ideas to social work practice. The student researcher has a commercial contract with Palgrave Macmillan to produce a new book, titled The Challenge of Existential Social Work Practice. Vignettes highlighting existential practice issues and approaches will be used in the book to demonstrate the application of existential ideas in social work.

Social casework developed out of the lived experience of the first social workers. Existential ideas have shaped social work throughout its history, but this has not been fully explored in previous social work texts. Existential ideas include freedom and responsibility, the idea that no system of thought can fully encompass human potential, the inevitability of choice and commitment in life, being fully present and available in social work for others, and the value of people's lived experience as an evidence base in social work practice.

The book may also contain discussion of some existential issues that social workers face in working with clients, such as loss of or search for meaning, anxiety, loss, finality and fate, and authenticity. However existential social work is an approach applicable to a broad range of fields of service, and it is not confined to dealing with existential issues.

The aim of the book is to show how existential social work practice can 
apply in all areas of social work practice, such as direct service, group work, social action and social policy.

Most of the vignettes derived from the focus group sessions are expected to relate to direct practice, but fictitious vignettes that highlight the other areas of social work practice will also be sought. The same principles apply to all fields. The vignettes can be formed around the social worker's practical experience, but the vignette as presented must be entirely fictitious.

What is Four focus group sessions of two hours' duration will be conducted by the involved student researcher using online technology to allow interstate and overseas practitioners to participate. Participants from Melbourne may prefer to meet the student researcher at the Burwood Campus of Deakin University at the specified location. They can also choose to participate online.

Each session will begin with a 25 minute introduction from the student researcher on such topics as:

- What do we mean by existential social work?

- $\quad$ The history of existential thinking in social work

- $\quad$ The challenges of existential social work

- $\quad$ The need for case examples or vignettes

Two anonymized vignettes will be presented and discussed per session by the participants.

How to get Please contact the PhD student researcher, Mark Griffiths.

involved

Institution Deakin University, Faculty of Health, School of Health and Social

Development, Social Work

Principal Professor Bob Pease

Investigator

Contact and Mark Griffiths

Student

Investigator 


\section{Bibliography}

Aho, K. 2014, Existentialism: An Introduction, Polity Press, Cambridge.

Barber J. 1991, Beyond Casework, Macmillan Education, London.

Barnes, H. 1959, The Literature of Possibility, Tavistock, London.

Barnes, H. 1997, The Story I Tell Myself, University of Chicago Press, Chicago.

Barrett, W. 1956, 'What is existentialism?’, Saturday Evening Post, 27 October, pp. 127-130.

Barrett, W. (1961), Irrational Man: A Study in Existential Philosophy. Tavistock, London.

Bartlett, H. 1971, 'Social Work Fields of Service', in Encyclopedia of Social Work, Vol 2, (16th edn), (ed Morris, R.) National Association of Social Workers, New York, pp. 1477-1481. Brandon, D. 1990, Zen in the Art of Helping, Penguin, London.

Brandon, D. and Jordan, B. (eds), 1979, Creative Social Work, Blackwell, Oxford. Bugbee, H. 1961, The Inward Morning, Collier Books, New York.

Camus, A. 1958, Exile and the Kingdom, Hamilton, London.

Camus, A. 2000, The Rebel, Penguin, London.

Cannon, B. 1991, Sartre and Psychoanalysis, University Press of Kansas, Lawrence.

Cohn, H. 2002, Heidegger and the Roots of Existential Therapy, Continuum, London.

Collins, J. 1952, The Existentialists, A Critical Study, H. Regnery, Chicago.

Collins, J. 1962, Crossroads in Philosophy, Gateway, Henry Regnery, USA.

Corey, G. 2013, Theory and Practice of Counselling and Psychotherapy, Brooks/Cole, Belmont.

Dreyfus, H. 2012, "'What a Monster then is Man": Pascal and Kierkegaard on Being a Contradictory Self and What to do About It', in Cambridge Companion to Existentialism, (ed Crowell, S. G.) Cambridge University Press, New York, pp. 96110. 
Flynn, T. 2006, 'Towards the Concrete: Marcel as Existentialist', American Catholic Philosophical Quarterly, vol. 80, no. 3, pp. 355-367.

Fook, J. Gardner F (ed) 2013, Critical Reflection in Context, Routledge, New York.

Frankl, V. 2004, Man’s Search for Meaning, Rider, Random House, Croydon.

Freud S. Breuer J. 2001, The Standard Edition of the Complete Psychological Works of Sigmund Freud, Volume 2: Studies on Hysteria, Vintage, London.

Fuller, R. Petch, A. 1995, The Reflective Social Worker, Open University, Buckingham.

Gordon, L. (ed), 1997, Existence in Black, Routledge, London.

Gordon, L. 2008, 'Sartre and Black Existentialism’, in Race after Sartre, (ed Judaken, J.) University of New York Press, Albany, pp. 157-170.

Griffiths, M. 2016, ‘Applying Gabriel Marcel’s Thought in Social Work Practice’, Marcel Studies, vol. 1, no. 1, pp. 24-39.

Guttmann, D. 1996, Logotherapy for the Helping Professional: Meaningful Social Work, Springer Publishing Co., New York.

Habermas, J. 1986, The Theory of Communicative Action, Polity Press, Cambridge.

Heidegger, M. 2002, The Essence of Truth, Continuum, New York.

Heidegger, M. (ed Medard, B.), 2001, Zollikon Seminars: Protocols, Conversations, Letters, Northwestern University Press, Evanston.

Hegel, G. (trans. Knox, T. M.), 1948, Early Theological Writings, University of Chicago Press, Chicago.

Hoey, J. 1953, 'Public Welfare: Burden or Opportunity?', Social Services Review, vol. 27, no. 4, pp. 377-384.

Ivanoff, A., Blythe B. and Tripodi T. 1994, Involuntary Clients in Social Work Practice, Aldine De Gruyter, New York.

Jacobson, B. 2007, Invitation to Existential Psychology, John Wiley and Sons, London. 
Jenkins, A. 2001, Invitations To Responsibility, Dulwich Centre, Adelaide.

Jenkins, A. 2009, Becoming Ethical, Russell House, Dorset.

Joseph, F. and Reynolds J. 2011, 'Existentialism, Phenomenology and Philosophical Method' in The Continuum Companion to Existentialism, (eds. Joseph, F., Reynolds, J. and Woodward, A.) Continuum, New York, pp. 15-35.

Joseph, F. 2005, Phenomenologies of the Lived Body: Husserl, Stein, Merleau-Ponty and Marcel on Embodiment, PhD Thesis, Baillieu Library, University of Melbourne, Melbourne.

Kaufmann, W. 1972, Existentialism from Dostoevsky to Sartre, World Publishing, New York.

Kaufmann, W. 1973, Without Guilt and Justice, P. H. Wyden, New York.

Konopka, G. 1963, Social Group Work, Prentice Hall, New Jersey.

Krill, D. 1978, Existential Social Work, Free Press, New York.

Laing, R. D. 1971, The Politics of the Family and Other Essays, Tavistock Publications, London.

Lantz, J. 2000, Meaning Centred Marital and Family Therapy, Charles C Thomas, Sprinfield.

Lantz, J. and Walsh, J. 2007, Short-Term Existential Intervention in Clinical Practice, Lyceum, Chicago.

Levinas, E. 1995, The Theory of Intuition in Husserl's Phenomenology, North Western University Press, Evanston.

Luijpen, W. 1960, Existential Phenomenology, Duquesne University Press, Louvain.

Marcel, G. 1966, The Philosophy of Existentialism, The Citadel Press, New York.

Marcel, G 1987, "Primary and Secondary Reflection” in Busch, T. (ed.) The Participant Perspective, University Press of America, Lamham, pp. 111-140.

Matustik, M. 1993, Postnational Identity, Guildford Press, New York. 
May, R. 1950, The Meaning of Anxiety, Roland Press, New York.

Merleau-Ponty, M. 1964, 'Hegel's Existentialism', in Sense and Non-sense, (ed MerleauPonty, M.) Northwestern University Press, Evanston, pp. 127-33.

Miller, R. 2016, 'Embedding Critical Social Work in Child Protection Practice', in Doing Critical Social Work, (eds Pease, B., Goldingay, S., Hosken, N. and Nipperess, S.), Allen and Unwin, Crows Nest.

Miller, R. 2008, Buddhist Existentialism, Shogam Publications, North Carlton.

Moyer, B. 2001, Doing Democracy, New Society Publications Canada.

Munro, E. 2008, Effective Child Protection, Sage London.

Nhat Hanh, T. 1997, Living Buddha, Living Christ, Riverhead Trade, New York.

O’Bassey, M. 2007, 'What is Africana Critical Theory or Black Existential Philosophy?', Journal of Black Studies, vol. 37, no. 6, pp. 914-935.

Reamer, F. 1993, The Philosophical Foundations of Social Work, Columbia University Press, New York.

Richert, A. 2010, Integrating Existential and Narrative Therapy, Duquesne University Press, Pittsburgh Pennsylvania.

Richmond, M. 1922, What is Social Casework?, Russell Sage Foundation, New York.

Rogers, C. 1980, A Way of Being, Houghton Mifflin Company, Boston.

Rowan, J. 2010, Personification, Routledge, New York.

Rowan, J. 2005, The Transpersonal, Routledge, London.

Rowan, J. 1997, Healing the Male Psyche, Routledge, New York.

Sartre, J. 1992, Truth and Existence, University of Chicago Press, Chicago.

Sartre, J. 2007, Existentialism is a Humanism, Yale University Press, New Haven.

Sartre, J. 2004, Critique of Dialectical Reasoning, Volume 1, Verso, Paris. 
Shapiro, J. 2016, Pragmatic Existential Counselling and Psychotherapy, SAGE Publications, Thousand Oaks.

Solomon, R. 1978, From Hegel to Existentialism, Oxford University Press, New York.

Spinelli, E. 2005, Practicing Existential Psychotherapy: The Relational World, SAGE Publications, London.

Stein, E. 2007, 'Martin Heidegger's Existential Philosophy', Maynooth Philosophical Papers, no. 4, p. 55-98.

Stewart, J. 2003, Kierkegaard's Relations to Hegel Reconsidered, Cambridge University Press, Cambridge.

Stewart, J. 2010, Idealism and Existentialism, Continuum, London.

Sutton, R. 1992, Human Existence and Theodicy, Peter Lang, New York.

Taft, J 1928, ‘The Spirit of Social Work’ The Family, vol. 9, no. 4, pp 103-107.

Thompson, N. 2006, Anti-discriminatory Practice, Palgrave Macmillan, Hampshire.

Thompson, N. 1992, Existentialism and Social Work, Ashgate, Aldershot.

Thompson, N. 2008, 'Existentialist Ethics: From Nietzsche to Sartre and beyond', Ethics and Social Welfare, vol 2, no. 1, pp. 1-23.

Tillich, P. 1962, 'The Philosophy of Social Work', Social Service Quarterly, vol. 36, no. 1, pp. 13-16.

Tillich, P. 2000, The Courage To Be, Yale University Press, New Haven.

Trotter, C. 2015, Working with Involuntary Clients, Routledge, New York.

Van Deurzen, E. 2010, Skills in Existential Counselling and Psychotherapy, SAGE Publications, London.

Wallace, R. 2005, Hegel's Philosophy of Reality, Freedom and God, Cambridge University Press, New York. 
Welsh, S. 2015, Existential Eroticism, Lexington Books, London.

Wilber, K. 2010, A Theory of Everything, Shambhala, Boston.

Wilkes, R. 1981, Social Work with Underprivileged Groups, Tavistock, New York.

Yalom, I. 1980, Existential Psychotherapy, Basic Books, Harper Collins Publishers, New York. 